\title{
تحليل الأستثمار السياحي \\ دراسة لاراء عينة من المديرين في المنظلات السياحية في إقليم كردستان العراق
}

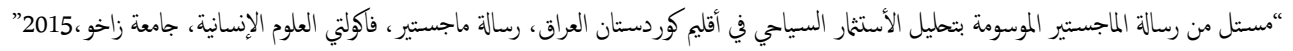

نافسر عبد القادر عبدال

الكلية التقنية الادارية-جامعة بولينكنيك دهوك

إقليم كردستان العراق
د. خيري علي اوسو

استاذ

الكلية التقنية الادارية-جامعة بوليتكنيك دهوك

إقليم كردستان العراق

المستخلص

هدفت الدراسة الحالية المى تحليل الاستثار السياحي في اقليم كوردستان العراق ، وتثثلت مشكلة الدراسة بان قطاعات الاقتصاد الوطني في الاقليم تعاني من الضعف والاهمال

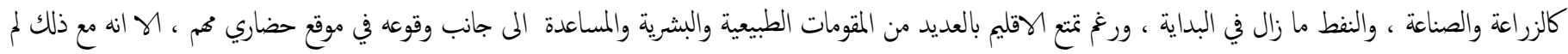

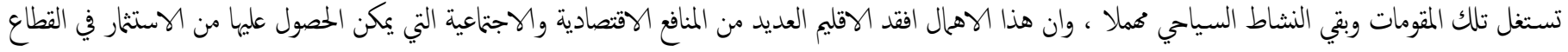

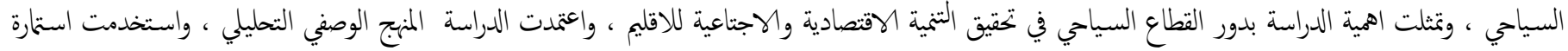

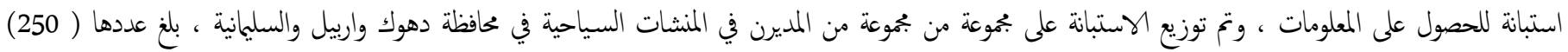

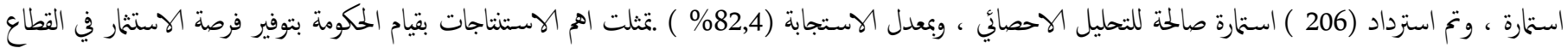

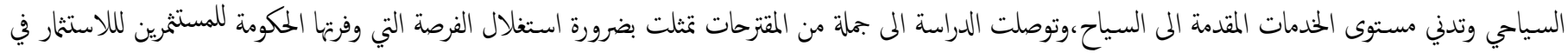
القطاع السياحي،وتحسين مستوى الخدمات المقدمة المى السياح. الكلمات المفتاحية: الاستثمر السياحي

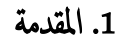

الماضية فقد كان عدد السياح عام 1995 (530) مليون سائ وصل في عام 2013 ألى مليار وخمسة وثلاثون مليون سائ، اما فيا يخص الايرادات السياحية الدولية فيلاحظ تطور هذه الايرادات خلال الفترة (1990 - 2012)، فقد زادت من (264) مليار دولار عام (1990) الى (1075) مليار دولار عام (2012) بزيادة قدرها (811) مليار دولار.متعد السياحة من المنظور الاجتاعي والحضاري حركة ديناميكية ترتبط بالجوانب الثقافية والحضارية للانسان وأنها بمثابة رسالة حضارية وجسر للتواصل بين الثقافات والمعارف الانسانية للام والشعوب ومحصلة طبيعية لتطور المجتمعات السياحية وارتفاع مستوى معيشة الفرد. وعلى الصعيد البيئي تحقق السياحة منفعة كبيرة للبيئة عن طريق التدابير المتميزة لماية السمات المادية للبيئة والمواقع والمعالم التاريخية والحياة البرية، وعادة ما يكون التزفيه والسياحة الهدفين الثانويين من انشاء وتنمية المواقع الوطنية، وانواع اخرى من المناطق
تعد السياحة ظاهرة بشرية قديمة، بدات مع وجود الانسان وكان اساسها عمليات انتقال الافراد من مكان الى اخر لتحقيق اهداق معينة كجمع القوت والتجارة وحب الاستطلاع والدين وغيرها.

اما اليوم فقد اصبحت السياحة حركة انسانية هدفها المنعة والاستجام واكتساب الثقافات المختلفة وتعميق الصلات بين الشعوب، كما اصبحت واقعا حضاريا ونشاطا اقتصاديا واجتاعيا يضم مرافق عديدة تخترق قطاعات مختلفة. ان لصناعة السياحة إثر كير على ميزان المدفوعات ويعد أحد القنوات المهمة للحصول على العملات الاجنبية والمساهمة في سد العجز المادي في الميزانية او التخفيف منه. ووفقا لاحصاءات منظمة السياحة العالمية فان قطاع السياحة العلمي قد حقق نموا قياسيا خلال السنوات

المجلة الاكاديمية لجامعة نوروز, الجملد 9, العدد 1 (2020)

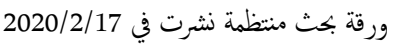

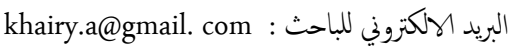
حقوق الطبع والنشر (؟) 2017 أسهاء المؤلفين. هذه مقالة الوصول الهيا مفتوح موزعة تحت رخصة CC BY-NC-ND 4.0 - المشاع الايداعي النسبي ولني 
أستثمري ملائم وذلك من خلال توفير الأمن والأستقرار السياسي في عموم

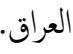
ب. دراسة (حمد 2008)، تخطيط وتنمية خدمات السياحة الدينية وأثرها في نو الطلب السياحي في محافظة نينوى. هدفت الدراسة الى بيان أهمية السياحة الدينية والنهوض بها،وكذلك تحديد نقاط القوة ونقاط الضعف للخدمات المقدمة للسياح في المحافظة من خلال تخطيط وتنمية الخدمات المتعلقة بطبيعة الموقع

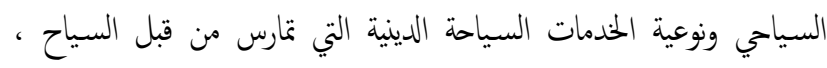
وتوضيح مقدار وججم تأهيل خدمات الايواء كالفنادق والمطاعز والنقل ....الخ على نمو النشاط السياحي ، واعتمدت الدراسة على المنهج الوصفي التحليلي ، وتم استخدام الاستبانة لاستطلاع اراء العينة ، تثثلت اهم الاستنتاجات بعدم وجود رقابة صحية سياحية جيدة على فنادق ومطاعز المحافظة بدرجاتها المختلفة ، وعدم الأهتام ، الكافي بالنسيج الثقافي والحضاري القديم للمحافظة والذي يشكل بدوره عامل جذب سياحي كير، فضلا عن وجود اهمال ونقص في خدمات النقل بكافة وسائلها بالاضافة الى تقادما ورداءتها الأمر الذي يتعذر عليها خدمة أنماط السياحة ومنها السياحة الدينية ، وتوصل البحث الى مجموعة من المقترحات من اهما التزكيز على التخطيط السياحي السليم لأغراض التنمية المكانية لما تعانيه المحافظة من تجاوز على المواقع الدينية والأثرية والثقافية ، والعمل على تنشيط أثماط أخرى من السياحة في المحافظة كالسياحة العلاجية وسياحة الصيد ، بالاضافة الى السياحة الدينية ، وأستخدام وسائل نقل حديثة لنقل السياح من والى المحافظة والعمل من أجل تنمية الطلب السياحي الديني والأثري والعلاجي وذلك من خلال وسائل الدعاية والاعلام السياحي المتخصص لكي يعرف الزوار بالموروث الحضاري والديني والتأريخي وبالمنافع العلاجية لما تمتلكه المحافظة من مقومات جذب السياحي. دراسة (بوعموشة 2012)، دور القطاع السياحي في تمويل الاقتصاد الوطني لتحقيق التنمية المستدامة-دراسة حالة الجزائر. هدفت الدراسة الى معرفة مساهمة القطاع السياحي في النهوض بالاقتصاد الوطني وتحقيق تنمية مستدامة ، وإبراز القطاع السياحي كقطاع مساهم في تويل الاقتصاد الوطني بالعملة الأجنبية ، وكذلك إبراز بجود الدولة من خلال إتباع بموعة من البرامج و السياسات وهل هناك تشجيع للنهوض بهذا القطاع من خلال الاستثمر المحلي
الجميلة، لذلك اصبحت المناطق الطبيعية عوامل الجذب الاساسية للسياحة الطبيعية والاكولوجية.

تعد بيئة اقليم كردستان العراق بيئة غنية بالمقومات السياحية، اذيتمع الاقليم بالثراء الطبيعي والمناخ اللطيف، المى جانب وقوع الاقليم في موقع حضاري مم مرت عليه الحضارات، وتركت فيه اثارا خالدة الى الابد. هذه المقومات تثير الافراد وتدفعه الى السفر نحو مناطق تواجدها. ومن هنا ظهرت الحاجة الى تناول موضوع تطوير القطاع السياحي في اقليم كوردستان العراق، دراسة استطلاعية لاراء عينة من المديرين في المنشات السياحية في أقليم

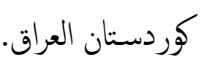

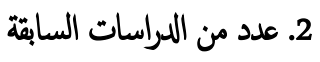
استكمالا للإطار النظري للبحث يستلزم الأمر استعراض مجموعة من الدراسات

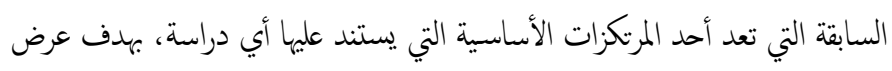
جهود الكتاب والباحثين في هذا المجال خلال السنوات السابقة، ومدى تجانس وتوافق الدراسة مع الدراسات السابقة، مع بيان ما يميز الدراسة عن هذه الدراسات، وفيم ياتي

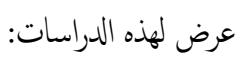

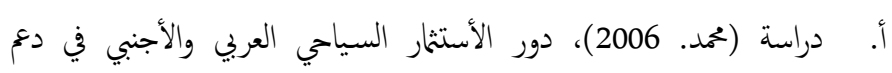
الأقتصاد العراقي/دراسة تطبيقية في محافظة كربلاء. هدفت الدراسة المى التعرف على المواقع السياحية الدينية والأثرية والتأريخية في محافظة كربلاء ، وايضا النعرف على مجالات وامكانية الأستثار العربي والأجنبي في المحافظة، وكذلك معرفة المقومات الأخرى لدع التوجه الأستثماري ، واعتمدت الدراسة على المنهج الوصفي التحليلي ، وتم استخدام الاستبانة لاستطلاع اراء العينة ، تمثلت اهم الاستناجات بأخغاض مساهمة قطاع السياحي في الدخل القوي وذلك بسبب عدم الأهتام بالسياحة اضافة المى الظروف التي مر بها البلد في الفترات الماضية ، وعدم فتح المجال أمام الأستثمارات العربية والأجنبية للأطلاع على الفرص الأستثمربة المتاحة في البلد ، اضافة الى عدم توفر الظروف والمناخ الأستثمري المناسب والمشجع للمستثمر العربي والأجنبي للقدور وأتخاذ قرارات في بجال الأستثمار السياحي ، وتوصل البحث الى مجموعة من المقترحات من اهمها خلق وتهيئة عوامل الجذب للقطاع السياحي ، وكذلك العمل على خلق مناخ 
العينة ، تمثلت اهم الاستنتاجات بأن الاستثمار في قطاع السياحة يوفر فرصا جديدة لجذب الاموال والترويج لثقافة التضامن. تقو.يم الدراسات السابقة يتضح من عرض الدراسات السابقة التي قدما بموعة من الباحثين في دراسة القطاع السياحي، أنها ساهت بشكل كبير في اغناء هذه الدراسة وساعدت الباحث في كنابة الجانب النظري والاستفادة منها في الجانب الميداني، واستناداً إلى ماسبق يككن تحديد عدد من المؤشرات للدراسات

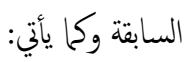

تنوعت الدراسات السابقة بين العربية والاجنبة، والتي تختلف من حيث العناوين والمنهجية المستخدمة ونوع العينة ومجتع الدراسة والنتاجُ

$$
\text { والتوصيات التي توصلت اليها. }
$$

التعرف على بعض المصادر العلمية التي تناولت موضوع القطاع السياحي. التعرف على المنهجية المعتمدة لهذه الدراسات وطبيعة متغيراتها. ساعدت على اعطاء تصور عن مجتمعات الدراسة وطبيعها فضلا عن أهميها في توضيح ججالات الدراسة المنتخبة لاجراء هذه الدراسات. ساعدت في التعرف على أهم الأساليب الاحصائية المستخدمة في جمع

$$
\text { ساعدت الباحث في تصميم استمارة الاستبيان. }
$$

إن التوجه المغاير للدراسة الحالية هو تناوله لموضوع تحليل الاستثار السياحي في اقليم كوردستان العراق، وهي بيئة تختلف عن بيئة بعض

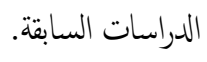

3. منهجية الدراسة

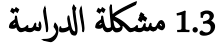

يعد القطاع السياحي احد القطاعات الأساسية للاقتصاد في إقليم كوردستان، الا انه يواجه العديد من المعوقات التي حال حتى الان دون وصوله الى المستوى المطلوب، رغز متع الاقليم بالعديد من المقومات الطبيعية والبشرية والمساعدة الى جانب وقوعه في موقع حضاري قمم، الح انه مع ذلك لم تستثمر تلك المقومات السياحية بالشكل المطلوب وبقي النشاط السياحي تهملا ،وان هذا الاهمال افقد الاقليم العديد من
والاجنب، و اعتمدت الدراسة على المنجج الوصفي التحليلي ، وتم استخدام الاستبانة لاستطلاع اراء العينة ، تمثلت اهم الاستنتاجات بوجود ضعف في أداء القطاع السياحي في الجزائر ويعود ضعف الاستثمار في هذا القطاع الذي كان بعد الاستقلال وما تبعه من مخططات أعطت الأولوية لقطاع الصناعات الثقيلة على حساب قطاع الخدمات بصفة عامة و السياحة بصفة خاصة ، وعدم توفر الاستقرار السياسي والمؤسساتي كان من الأسباب التي لعبت دورا هاما في تعطيل واههال هذا القطاع رافقها تراجع في عدد الوافدين ، وكذلك ضعف نوعية المنتج السياحي بالرغ من المؤهلات المميزة الح انه غير تنافسي فيا يخص نوعية المدمات السياحية المقدمةعلى مستوى المؤسسات الفندقية وهياكل الاستقبال التي تتميز هي الأخرى بضعف طاقاتها وعدم احتراما للمعايير المعمول بها عالميا ، وتوصل البحث المى بموعة من المقترحات من اهها دع مناطق الجذب السياحي عموما ومنتجات السياحة البيئة على وجه الخصوص من أجل الحفاظ على الطابع البيئي الثقافي لتلك المناطق كما يجب التزكيز على تخطيط قطاع السياحة بالاعتماد على المعايير واللوائُ الدولية ، وكذلك تحسين جودة وكفاءة البنية الأساسية والخدمات المتعلقة بالسياحة مثل الفنادق والطرق والمرافق العامة و وسائل النقل والمواصلات من أجل تقديم خدمات سياحية على المستوى العالمي . ث. دراسة (Meihami \& Karami 2014)،

Review Some Effects of the Investment in the Tourism Sector (Evidence of the Qhorveh City) المتزتبة على الاستثمار في قطاع السياحة تعد صناعة السياحة من أكبر الصناعات في العالم، وواحد من أسرع القطاعات نموا، ويمثل أكثر من ثلث قيمة إجلالي تجارة الخدمات في جميع أنحاء العالم. وللسياحة دور كير في تحتيق التنمية الاقتصادية وتخفيض معدل البطالة ، حتى انه يمثل القوة الدافعة لاقتصاد أي بلد ، وتعد استخدام الموارد المحدودة كراس المال ، و والموارد المادية ، والقوى العاملة والموارد الطبيعية من تحقيق اهداف الدولة ، وان عدم استخدام هذه الموارد بشكل جيد من قبل المستتمرين يعد خسارة للمنظمة او الدولة ، ومن اجل تجنب هذه الخسائر يجب وضع خطة استثمارية مدروسة وتقيمها ، واعتمدت الدراسة على المنهج الوصفي التحليلي ، وتم استخدام الاستبانة لاستطلاع اراء 
توفير قاعدة من المعلومات والبيانات التي قد تساعد على تفعيل وتعزيز القطاع

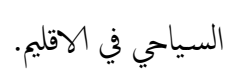

إبراز جهود الدولة من خلال إتباع بموعة من البرامج والسياسات ومدى

$$
\text { التشجيع للنهوض بهذا القطاع من خلال الاستثمر المحلي والأجنبي. }
$$

التعرف على جنسية السياح عراقين، عرب، اجانب، وكذلك النعرف على نقاط القوة والضعف في هذا القطاع ومحاولة ايجاد الحلول المناسبة لنقاط

$$
\text { الضعف، وتعزيز نقاط القوة. }
$$

\section{3}

بناءا على طبيعة الدراسة والاهداف التي تسعى الى تحتقيها فقد استخدم المنجج الوصفي التحليلي من خلال اعطاء شرح لمختلف مفاهيم السياحة، وكذلك استخدم المنهج التحليلي لتحليل البيانات التي يتم جمعها بواسطة استبيان تم تصميمه وتطويره

لهذه الغاية، ومن ثخ تحليل المعلومات وتفسيرها وصولا للاستنتاجات والمقترحات

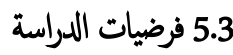

تستند الدراسة على بمموعة من الفرضيات الرئيسة تتمثل بالآتي:

يزداد الطلب السياحي في اقليم كوردستان سنويا وبشكل منتظم للفترة من

يتميز الطلب السياحي في اقليم كوردستان بالموسمية.

يتباين الطلب السياحي في اقليم كوردستان العراق حسب اماكن الاقامة. تنوع مصادر العرض السياحي في اقليم كودستان العراق. تنوع مجالات الاستثغرات السياحية في اقليم كوردستان العراق. ضعف الاستثمارات السياحية في اقليم كوردستان العراق.

تشجع التسهيلات والحوافز التي تقدما حكومة الاقليم للاستثمار في القطاع

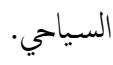

ضعف المنافسة بين المنشات السياحية في اقليم كوردستان العراق. ضعف الاساليب التسويقية والتزويية السياحية التي تقوم بها الحكومة. ضعف دور الهيئة العامة للسياحة في تنشيط الطلب السياحي والاستمار

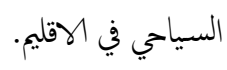

ضعف الدور الاقتصادي للقطاع السياحي في الاقليم. ضعف الدور الاجتماعي للقطاع السياحي في الاقليم.
المنافع الاقتصادية والاجتماعية التي يكن الحصول عليها من جراء الاستثمر في القطاع

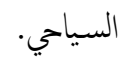

2.3 اهمية الدراسة

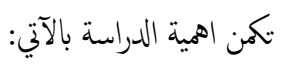

يمكن ان يصبح القطاع السياحي بديلا تنمويا، اذ يساهم في الحصول على العملات الاجنبية الصعبة، وتنشيط حركة الاقتصاد الوطني، وتقليل البطالة،

$$
\text { وتقليل الفوارق بين مختلف اقاليم الدولة .... الخُ. }
$$

سيفيد البحث القطاع الحكوي والخاص بإعادة النظر في توبهانهم بخصوص

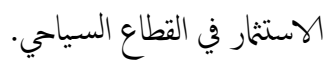
وتعد السياحة من المنظور الاجتاعي والحضاري حركة ديناميكية ترتبط بالجوانب الثقافية والحضارية للانسان وأنها بمثابة رسالة حضارية وجسر للتواصل بين الثقافات والمعارف الانسانية للام والشعوب ومحصلة طبيعية لتطور المجتمعات السياحية وارتفاع مستوى معيشة الفرد. وعلى الصعيد البيئي تحقق السياحة منفعة كيرة عن طريق الندابير الحفازة لماية السمات المادية للبيئة والمواقع والمعالم التاريخية والحياة البرية.

3.3 اهداف المراسة تسعى الدراسة الحالية الى تحقيق الاهداف الاتية: - - التعرف على واقع الاستثمار السياحي في اقليم كوردستان العراق. - - التعرف على العوامل التي تشجع او تعيق الاستثمر السياحي في الاقليم. - - - النعرف على دور القطاع الخاص في تحقيق متطلبات الاسثمار في الاقليم. - - النعرف على مفهوم السياحة، وعلى مقومات الجذب السياحي في الاقليم بالاستفادة مما طرحته الادبيات التي اتيح للباحث مراجعتها، وتقديم اسهام

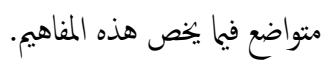
- - التعرف على أهمية السياحة في رفع معدلات النمو الاقتصادي، ودع التنمية في الاقليم. - - تقديم بموعة من التوصيات بما يؤدي إلى مساعدة الجهات على استثمار القطاع السياحي بشكل أفضل لتحقيق أهدافها بكفاءة وفاعلية. 
تعد صناعة السياحة من أكثر الصناعات نموا في العالم، وتضم العديد من القطاعات الأقتصادية والأجتاعية، مما يجعلها قاطرة التنمية في أي بلد، وقد أظهرت الأستطلاعات أيضا بأن السياحة هي الصناعة الأولى لترويج الأستثار في جميع أنخاء العالم

.(Endo,2006: 600)

يعد الأستثار في القطاع السياحي ضرورة ملحة لتنويع مصادر الأقتصاد في اقليم كوردستان العراق بدلا من الاعتماد على مصدر واحد للاقتصاد وهو النفط، لذلك أصبح من الضروري التوجه نحو تنويع مصادر الأقتصاد لتحقيق الأهداف الأجتاعية والأقتصادية في الاقليم، وان أستتباب الأمن والأستقرار في الاقليم يعد من العوامل الأساسية لتوفير بيئة مناسبة للمستتمرين للاستثمار في مختلف القطاعات الأقتصادية للاقليم ومنها قطاع السياحة، اذيمنلك الاقليم العديد من المقومات السياحية الطبيعية والتاريخية والاثرية المتنوعة، لذا لابد على أصحاب القرار في اقليم كوردستان عرض الفرص الأستثارية المتوفرة في قطاع السياحة، والقيام بدورهم في هذا الاتجاه من خلال بلورة وتصميم ستراتيجية لتنمية هذا القطاع وتسهيل فعالياته على أساس المنافسة الأقتصادية السليمة وفق اليات أقتصاد السوق، اذ أن الأستثار في القطاع السياحي يعد من المجالات الأستثارية المربكة، والتي تعطي مردودات مالية كبيرة اذا أعتمدت على أسس سليمة، اذ أن الاقليم يمناك بيئة سياحية مليئة بالمقومات السياحية، لذلك لابد من فتح باب الأستثمار في هذا الجمال، وتأسيس بنية تحتية متطورة تتناسب مع البيئة السياحية المتوفرة باعتماد تكنولوجيا المعلومات والاتصالات المتطورة كبناء الفنادق المتطورة, ومطارات وبمعات تجارية وطرق ومدن سياحية متكمالة من شأهها أن تحقق جذبا سياحيا هما . ان الاستثار في القطاع السياحي لا بهدف فقط لجذب رؤوس الأموال، ولكن أيضا لجذب رأس المال البشري، كرجال الأعال، والضيافة، ومدراء وكالات السفر والسياحة، والعديد من الامتيازات الدولية (UNWTO, 2007). يعمل الأستثار السياحي الناحح على توفير رؤوس الأموال وتوجيها إلى إقامة مشروعات سياحية سواء في جانب العرض السياحي كالفنادق والمنتجعات والقرى السياحية والمطاع والمتنزهات والأماكن السياحية والمزارات الدينية وشركات النقل السياحي وغيرها، أو في جانب الطلب السياحي كلمعارض وشركات التسويق والترويج والكعلام وغيرها، أو في جانبي الطلب والعرض كما في شركات ووكلات السفر والسياحة التي تتعامل مع الطرفين، ولا تقتصر رؤوس الأموال على رؤوس
يؤيد المديرين للنشات السياحية في الاقليم مبدأ الشراكة ما بين القطاع العام

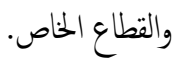

6.3 اسباب اختيار الموضوع ان المبررات التي دفح الباحثان لاختيار الموضوع تتمثل بالآتي:

الحصول على العديد من المنافع الاقتصادية والاجتاعية نتيجة الاستثمر في

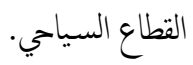

دور قطاع السياحة في دع الاقتصاد الوطني ومساعدته على تجاوز التحديات الراهنة التي توابجه، إذا ما ثمّت الاستفادة من هذا القطاع الواعد بالشكل

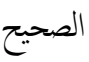
المساهمة في رفع الوعي السياحي ونشر ثقافة السياحة في اقليم كوردستان

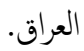
الاهتمام المتزايد وخاصة في الاونة الاخيرة من قبل حكومة الاقليم بالقطاع السياحي لدوره في تحتيق التنمية الاقتصادية والاجتاعية للاقليم. نظرا لكون القطاع السياحي ذو مرافق متعددة وأنشطة مختلفة، يمكن من خلالها الخروج بنتأُج مفيدة تلاءم العديد من المنشات الأخرى. امكانية الحصول على العديد من البيانات الذي تتطلهيا الدراسة. قطاع خدي له أهمية كبيرة في الجمتعع وركن أساسي من أركان الاقتصاد، فضلا عن كنها مصدرا من مصادر الحصول على العملات الصعبة لتنفيذ خطط التنمية الشاملة، وتوفير الخدمات للأفراد. ان القطاع السياحي بات اليوم حقل نشاط واسع تستوعب أعداد كبيرة من الايدي العاملة كوظفين ومشرفين وغيرها مما تساعد على تقليل نسبة البطالة في

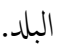
تعليم وتدريب الأفراد العاملين في المجالات المختلفة ورفع المستوى العمراني في البلد وتحقيق التوازن بين مختلف اقالمه، فضلا عن الأعلام عن نهضة البلد وتحتيق السلام العالمي، وهي بذلك تعد إحدى المستلزمات الضرورية الحديثة، ولا يكن لأحد إن يتصور بلد متحضر دون إن يمتلك منشات فندقية يسمح بإقامة السياح فيها لضرورة العمل أو الاستجام أو أية وسيلة.

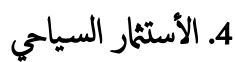

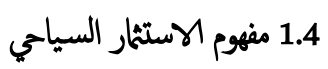


أما القانون البريطاني فقد عرفت منشات الايواء بأنه المكان الذي يتلقى فيه المسافر خدمات المأوى والطعام مقابل سعر محدد قادر على دفعه، في حين عرف ويبستر الفندق: بأنه مبنى أو مؤسسة تمد الجمهور بالاقامة والطعام والخدمة (عبد العزيز،

وعليه فنشات الايواء تؤمن وسائل الراحة والسكن للسياح، وتتمثل الحذدة الرئيسية له في توفير غرف النوم، وأن معظم الفنادق تقدم الطعام والشراب وخدمات التسلية والتزفيه، وتوفر الكثير منها قاعات وخدمات للاجتاعات، ويضم بعض تلك المنشات المحلات التجارية، وتتراوح أبجامها بين منظطات ضخمة تضم أكثر من ثلاثة آلاف غرفة، ومنشات صغيرة تحتوي على أقل من عشر غرف، وهناك أختلاف في نوعية الخدمات بين المنشات الكبيرة والتي تتميز بجودة عالية وأسعار غالية، والمنشات الصغير الحجم تكون خدماتها مناسبة وأسعارها منخفضة، ويوظف العديد من منظلات الايواء الحديثة موظفا واحدا لكل غرفتين تقريبا، ويعمل الموظفون على مدى أربع وعشرين ساعة في اليوم من أجل توفير الخدمات المى السياح، وتوفر معظم مطاعم منشات الايواء خدمة الغرف التي يستطع السائُ عن طريقها طلب إحضار الطعام والشراب إليه في غرفنه، كذلك بإمكان السياح أن يطلبوا غسيل ملابسهم وكيها، ويتقاضى بعض هذه المنشات من الزبائن أجرة الغرفة فقط، أما الوجبات الغذائية والخدمات الأخرى فهي تخضع لرسوم إضافية، كما يقدم العديد من هذه المنشات خدمات الطعام والنوم بسعر محدد إما أن تقدم وجبة الإفطار فقط أو وجبة الإفطار والعشاء. وينتشر في محافظات اقليم كوردستان العديد من المنشات السياحية كالفنادق والموتيلات والقرى السياحية، وكان عددها في تزايد مضطرد خلال الفتزة (20072014 )، فيلاحظ تزايد عدد الفنادق بشكل بطىء من (106) فندق خلال عام ( 2007) الى ( 385) فندق خلال عام ( 2014)، وتزايد أيضا عدد الموتيلات خلال تلك الفترة، فبعد أن كان عددها ( 49) موتيل عام ( 2007) وصل الى (284 ) عام) 2014)، كما تزايد عدد القرى السياحية من (29 ) قرية سياحية عام ( 2007) الى (75 ) قرية سياحية عام ( 2014)، وتزايد عدد الاسرة من ( 10451) عام ( 2007) الى ( 44504) عام ( 2014) ، الجدول (1 ). وتعد السياحة بشكل عام ومنشات الايواء بشكل خاص كرافد أساسي في التنمية الاقتصادية ولذلك نجد ضخامة الأستثارات الخمتلفة في القطاع السياحي، اذ تعتمد العديد من الدول على السياحة، كصدر عمم من مصادر الدخل الوطني،
الأموال الوطنية، وإنما ينضم إلها رأس المال الأجنبي من خارج الدولة، ويرتبط ذلك بتوفير مناخ ملائم من اكتمال البنى الأساسية والتشريعات الميسرة، والحوافز المشجعة، والمعلومات المتاحة بشفافية، ونظم الإدارة العامة المتطورة، كما يعد توفير دراسات الجدوى للمشاريع السياحية عنصرا أساسيا في حفز وجذب الأستثمار إليها ( بظاظو ،

.(7: 2012

تتباين آراء الكتاب والباحثين عند تحديد مفهوم الاستثار السياحي، ويعزى ذلك الى تباين توجحات الكناب والباحثين لمعايير ومجتمعات البحث وعيناتها، فضلا عن تباين المكان وفرضيات بحوثه، ولكن ما يككن تأكيده ان هذه التباينات لم تصل الى حدود التقاطع، بل ثمة قواسم مشتركة أفصحت عن مضامين متفق عليها بخصوص المفهوم وتشخيصها لنعريفات عديدة أقرته على نخو سليم، وفيما يأتي نستعرض عدد من هذه التعريفات: يعرف الاستثمار السياحي بكونه المجال الذي يسمح بخلق ثروة جديدة وتجديد الثروات القائمة، وهو أحد المراحل الرئيسة في الدورة الأقتصادية التي تتمثل في الانتاج، التوزيع، الأستهلاك، الادخار والاستثمار، وتؤكد الدراسات الاقتصادية بأن أرتفاع معدلات الادخار تساعد على أرتفاع معدلات الاستثمار، والعكس هو الصحيح

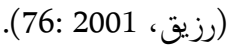

وبموجب ما سبق يمكن القول بأن الأسثمار السياحي عبارة عن خلق ثروة جديدة من خلال القيام بسلسلة من المصروفات على القطاع السياحي، وأنظظار الايرادات مستقبلا، ويعد الأستثمر في القطاع السياحي من الأنشطة الواعدة التي تتيح فرصا أستثمرية قادرة على المنافسة في سوق السياحة العالمية، ذلك أن رواج صناعة السياحة يوثر بشكل مباشر على أقتصاديات الدول، ونو الصناعات والأنثطة المرتبطة بصناعتها.

\section{4 مجالات الاستثار السياحي في اقليم كوردستان العراق 1.2.4 منشات الايواء}

يقصد بمنشات الايواء المكان الذي يستطع الأفراد المكوث والذين يحسنون التصرف ويستطيعون دفح أجور اقامته وتسليته والخدمات الأخرى كالطعام والشراب، فيكون لهم بمثابة بيت مؤقت، أي أنه بيت بعيد عن البيت، وتتوفر فيه جميع مستلزمات الراحة ولكن مقابل دفع أجور معينة (او نبعة، 2005: 155). 


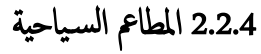

يشهد قطاع المطاع في العالم نشاطا ملحوظا ، حيث يستقطب هذا القطاع الاستثغرات العالمية والمحلية من مقيمين ومواطنين ، خاصة الشباب الذين يتطلعون لدخول عالم التجارة والأعال من خلال المشاريع الجديدة وعلى الرغز من الظروف الاقتصادية والاجتماعية الصعبة التي يمر بها العديد من الدول ، الا ان قطاع المطاعز يعد من أبرز القطاعات للاستثمار فيه ، وتمتلك محافظات اقليم كوردستان العديد من المطائ يككن الاستثمار فيه داخليا او خارجيا ، ويلاحظ تطور عد المطاع في اقليم كوردستان العراق ، فقد تزايد عددها من ( 129) مطعم عام ( 2007) الى ( 643) في عام ( 2014) ، الجدول (3).

الجدول (3) عدد المطائ السياحية خلال الفترة (2007-2014)

\begin{tabular}{|c|c|c|c|c|c|c|c|c|}
\hline حتى & 2013 & 2012 & 2011 & 2010 & 2009 & 2008 & 2007 & نوع المنظمة \\
\hline 643 & 565 & 482 & 338 & 305 & 233 & 129 & 129 & والمكافتريات \\
\hline
\end{tabular}

المصدر: احصاءات الهيئة العامة للسياحة في اقليم كوردستان لعام 2015

وفي سياق متصل يبلغ عدد المطائ من الدرجة الممثازة ذات المخس نجوم (11 )، وييلغ عدد مطاء الدرجة الأول ذات الاربعة نجوم ( 42) مطعم، ويبلغ مطاءم الدرجة الثانية ثلاثة نجوم ( 55)، وييلغ عدد مطاع الدرجة الثالثة نجمتان (144 ) مطعم، وييلغ عدد مطاع الدرجة الرابعة ذات النجمة الواحدة (161 )، وييلغ عدد المطاع الشعبية بدون درجات ( 230) مطعم، فيا يبلغ عدد المطاع الخاصة (1015 ) مطعم، وبذلك ييلغ عدد المطاع الكلية (1658 ) مطعم، وهي عدد قليل مقارنة بعدد السياح الداخلين الى اقليم كوردستان العراق خاصة اذا علمنا بأن السياح يبحثون دائما عن المطاع ذات الجودة العالية، الجدول (4 ).

الجدول (4) عدد المطام السياحية حسب الدرجات خلال الفترة حتى نهاية عام 2014

\begin{tabular}{|c|c|c|c|c|c|c|c|c|c|}
\hline العمام & الخاصة & المجموع & |درجة & |رابعة & $\mid$ & ثانية & \begin{tabular}{|l} 
| \\
${ }_{4}$
\end{tabular} & \begin{tabular}{|l|} 
\\
${ }_{5}$
\end{tabular} & المنظمة الدة \\
\hline 1658 & 1015 & 643 & 230 & 161 & 144 & 55 & 42 & 11 & والمكافزيات \\
\hline
\end{tabular}

وأستطاعت الحصول على مدخولات سنوية كبيرة من القطاع السياحي، أن الدخل السياحي له تأثير كير في أقتصاديات الدول السياحية، فهو يعزز ميزان المدفوعات ويعتبر مصدرا محما لتوفير فرص العمل مما يدع المستوى الأقتصادي والأجتاعي للأفراد، ولأهمية السياحة فقد أصبحت ترتبط بالتمية الاقتصادية أرتباطا وثيقا بعد أن كانت علاً ججردا يدرس في الجامعات والمعاهد، وتعتبر السياحة أحد العناصر الأساسية للنشاط الأقتصادي في الدول السياحية، اذ أن السائُ الذي يقصد دولة ما ينفق حوالي ( 31\%) من ميزانيته على الفنادق. الجدول (1)عدد المنثات السياحية خلال الفترة (2007-2014)

\begin{tabular}{|c|c|c|c|c|c|c|c|c|}
\hline حتى & 2013 & 2012 & 2011 & 2010 & 2009 & 2008 & 2007 & نوع المنظمة \\
\hline 385 & 314 & 259 & 202 & 168 & 131 & 116 & 106 & الفنادق \\
\hline 248 & 206 & 168 & 128 & 96 & 72 & 53 & 49 & الموتيلات \\
\hline 75 & 72 & 54 & 44 & 42 & 37 & 33 & 29 & السياحية \\
\hline 44504 & 34954 & 31634 & 26811 & 22533 & 13480 & 11363 & 10451 & عدد الاسرة \\
\hline 643 & 565 & 482 & 338 & 305 & 233 & 129 & 129 & والكافتريات \\
\hline
\end{tabular}

المصدر: احصاءات الهيئة العامة للسياحة في اقليم كردستان لعام 2015

وفي سياق متصل يبلغ عدد الفنادق من الدرجات المختلفة (385) فندق، وييلغ عدد الفنادق الخاصة (190) فندق، وبذلك يصبح مجموع الفنادق العامة والخاصة (575) فندق، ويبلغ عدد الموتيلات السياحية ذات الدرجات المختلفة (248) موتيل، وييلغ عدد الموتيلات الخاصة (84) موتيل، وبذلك يصبح بمحوع الموتيلا العامة والخاصة (332) موتيل، وييلغ بمحوع القرى السياحية ذات الدرجات المختلفة (75) قرية

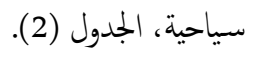

لجدول (2) عدد المنشات السياحية حسب المرجات حتى نهاية عام 2014

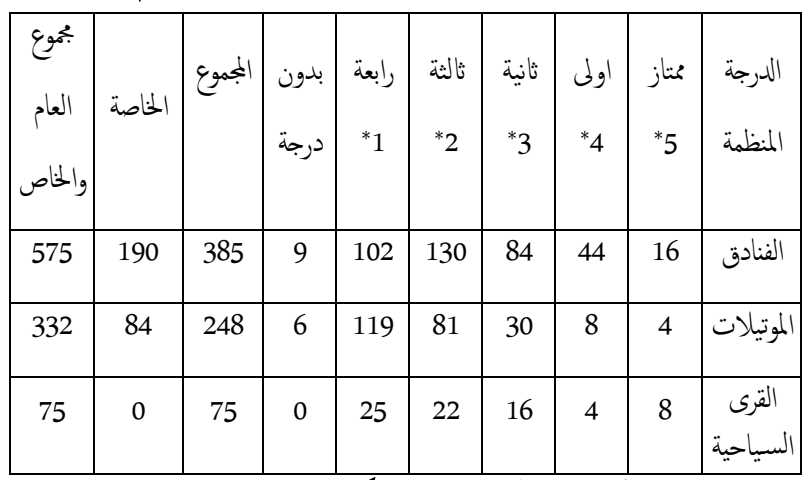

المصدر: احصاءات الهيئة العامة للسياحة في اقليم كوردستان لعام 2015 
من قيمة الانتاج بسعر المنتج، منها $(2781,9)$ مليون دينار مستلزمات خدمية و 631 ) مليون دينار مستلزمات سلعية. القيمة المضافة الاجاليةالمتحققة (7.0) مليار دينارفي حين بلغ فائض العمليات

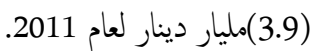
بلغ عدد العاملين في شركات السفر والسياحة (653) عامل. بلغت قيمة النفقات الرأسمالية لشركأت السفر والسياحة الموجودات الثابتة(52) مليار دينار في، 2011/1/1 في حين بلغت قيمة تكوين رأسمال الثابت (4.9)

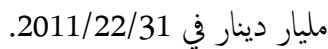

أظهرت نتاجُ المسح إن عدد المسافرين المنقولين لهذا النشاط (209078) مسافر منهم (19700) مسافر نقل داخلي وبنسبة (\% 9.4) في حينبلغ عدد المسافرين كان في النقل الخارجي(189378 ) مسافر وبنسبة (90,6\%) من

$$
\text { بمجوع المسافرين. }
$$

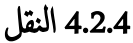

يشمل النقل مرافق البنة الأساسية من طرق وموانع ومطارات وما يتم إنتاجه من خدمات النقل بأستخدام هذه المرافق عبر وسائل النقل الختلفة بما في ذلك نقل المسافرين والبضائع بمختلف الأشكال والتراكيب والمكونات بين موقعين، ويكن أن يتم ذلك بأستخدام النقل البري، أو الجوي، أو البحري ، وفي مجال السياحة يأتي النقل البري في المرتبة الأولى من حيث الأهمية، اذ ينتقل القسم الأكبر من السياح عن طريق النقل البري الذي يحقق لمم فرصة النعرف بشكل أفضل على أكثر من موقع سياحي في الرحلة السياحية الواحدة ـ ولذلك يكون النصيب الأكبر من الحركة السياحية للدول التي تتوفر فيها وسائل نقل متطورة وشبكة طرق حديثة، كما أن العامل البارز في ججم الحركة السياحية هو أسعار النقل في المرتبة الأولى لما لها من تأثير واضح على تكليف السياحة، لنا فالنقل فرصة أستثارية أخرى يككن للمستثمرين ورجال الأعمال أستثمارها.

وتتضمن الأستثمار في مجال النقل المجالات الاتية: (البطاط والزويني، 2006: 320).

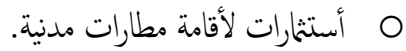
O أستثغرات لأقامة شبكة من الطرق مخصصة للأغراض السياحية.

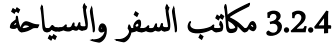

تساعد الناس على تنظيم الرحلات والعطل عن طريق عمل تدابير أستعدادهم للسفر ، فهي تحجز لهم غرفا في الفنادق، ومقاعد في وسائل النقل، كما تنظم لهم رحلات سياحية، وتعين لمم مرشدين سياحين يساعدونه في الحصول على جوازات السفر والتأشيرات التي يحتاج الهيا السياح أثناء السفر الى البلدان الأخرى، وتتولى كمة تنظم الرحلات السياحية للأفراد والجماعات، ويأتي معظم دخل وكلات السفر من العمولات التي تدفعها الخطوط الجوية وشركات تأجير السيارات والفنادق، ومدراء المنشات التي تخدم السياح، وتدفع هذه المنظات عمولة على كل جزز تقوم به أية وكالة سفر، أو على أية تذكة تبيعها، ولا يدف السياح أي مبالغ عن معظم الخدمات التي تقدم لمم، ولكن وكلات السفر يككن أن تتقاضى قسطاً من المال مقابل التخطيط للرحلات السياحية الفردية التي تتطلب الكثير من الوقت والجهد، وتعمل وكلات السفر في معظم بلدان العالم، وتكون مسؤولة عنها في معظم الأحيان جهات خاصة، كما أن الأظمة التي أملها الصناعة نفها قد ساعدت على تأسيس مقايس للسلوك الخلتي يلتزم بها أصحاب وكلات السفر والسياحة. وتنتشر في محافظات اقليم كوردستان العراق العديد من وكلات السفر والسياحة تتولى كمة تنظيم الرحلات السياحية وحجز تذاكر الطيران والفنادق والحصول على تأشيرات الدخول مقابل الحصول على مدخولات يكون له دور في تحسين معيشة أفرادها، وعليه فهي فرصة أستثمرية أخرى يكن المستثمرين ورجال الأعمال أستثرارها. وتشير احصاءات وزارة التخطيط في اقليم كوردستان لعام 2011 بأن عدد شركات السفر والسياحة التي تمارس النشاط السياحي بلغ (156) شركة، منها (83) شركة في محافظة أربيل وبنسبة (53,2\%)، تليها محافظة دهوك بعدد (42) شركة وبنسبة (26.9)، أما محافظة السليمنية فقد بلغ عددها (31) شركة وبنسبة (19,9\%) من المجموع الكلي، وحققت تلك الشركات الاتي:

حققت شركات السفر والسياحة قيمة إنتاج وبسعر المنتج ايرادات (10.4) مليار دينار ويمثل إيراد النقل (3,0) مليار دينار من قيمة الانتاج، يليه إيراد السياحة (2.9) مليار دينار (4,5) مليار دينار بقية الايرادات الأخرى. بلغت قيمة المستلزمات (3.4) مليار دينار وتشكل نسبة مقدارها (\% 32.7) 


\subsection{4 الألعاب والملاعب الرياضية}

تتمتع محافظات اقليم كوردستان العراق بوجود العديد من مدن الألعاب والملاعب والصالات الرياضية، لذلك فهي تجذب مختلف الأعمار والأجناس من السياح لتحقيق أعراض مختلفة، لذلك تعد هذه المدن والملاعب فرصة أستثمرية للمستثمرين ورجال

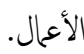

\section{5. الدراسة الميدانية}

\section{5}

أستند الجانب النظري من الدراسة على توظيف الطروحات الأكاديمية من رسائل ماجستير وأطاريخ دكتوراه وكنب ودوريات والأبحاث المنشورة في مواقع الأنتزيت المختلفة، وأستندت الدراسة في الجانب الميداني على أستارة الأستبيان بوصفها مصدرا أساسيا لمجع البيانات وروعي في تصميم الأستمارة أن تكون منسجمة مع واقع المنشات السياحية في اقليم كوردستان العراق، وتضمنت الأستارة مجموعة من الأسئلة، منها ما يتعلق بالمعلومات العامة ، ومنها ما يتعلق بمعلومات عن المنشات السياحية، ومنها ما يتعلق بواقع الأستثار السياحي في الاقليم، ومنها ما يتعلق بالمنافسة بين المنشات السياحية في الاقليم، ومنها ما يتعلق بالتسويق والتزويج السياحي، ومنها ما يتعلق بتقييم تجربة حكومة اقليم كوردستان في تفعيل الأستثار السياحي في الاقليم، ومنها ما يتعلق بدور الهيئة العامة للسياحة في تنشيط الطلب السياحي والأستثار فيه، ومنها ما يتعلق بالدور الأقتصادي والأجتمعي للقطاع السياحي في الاقليم. وتم عرض الأستارة في شكلها الأولي على بموعة من الخبراء والاختصاصيين في العلوم الإدارية والاقتصادية لإبداء آرائهم حول مدى صلاحية وفعالية الأسئلة المقترحة، ونتجت عنها ملاحظات تمت مناقشتها وإجراء التعديل اللازم عليها، وبذلك حصلت الأستمارة على موافقة الأغلبية من المكمين، الملحق ( 1 )، ومن أجل أختبار دقة الأستمارة في تعبيرها عن الظاهرة المدروسة تم إخضاع الأستارة إلى اختبار الثبات الذي يقيس دقة فقرات الأستارة عند تكرار الأختبار على بموعة من الأفراد، إذ قام الباحث بتوزيع الأستمارة على (15 ) فردا من أفراد العينة في شهر تموز عام 2015 ، وأعيد الاختبار ثانية بعد شهر على نفس المجموعة وتبين أن التطابق في إجابات أفراد العينة بلغ ( 85\% ) وهي نسبة تثبت درجة عالية من ثبات الاستارة، وبذلك أعتمد الاستمارة في شكلها النهائي قبل التوزيع، وتم توزيع الأستبانة على مديري المنشات السياحية على أعتبار أن هؤلاء لديهم خبرة في المجال السياحي وقدرة على التعبير عن واقع الحركة السياحية في توري
O أستثمرات خصصة لأقامة نقاط بريدية وأتصالات خدمية ضمن المرافق السياحية.

وبموجب ما سبق يعد قطاع النقل من القطاعات المهمة لما يؤدي من حمم في مختلف الأنشطة الأقتصادية والأجتاعية ومنها السياحة بالاضافة المى مساهنه في الناتج المحلي الاجالي وتشغيل الأيدي العاملة.

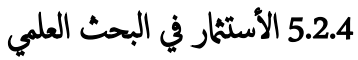

يعد البحث العلمي ركيزة أساسية من ركائز المعرفة الإنسانية في كافة ميادين الحياة، بل أضحى أحد مقايس الرقي والحضارة في العالم، فن خلال البحث العلمي يستطيع الإنسان اكتشاف المجهول وتسخيره لصالح المجتع بما يحقق التنمية والأزدهار في كافة مجالات الحياة، وبفضل البحث العلمي يككن أمتلاك التقنية والمعرفة بأعتبارها الأداة الفاعلة لتحقيق الأستثمار الأمثل للموارد المتاحة من أجل تحقيق التنمية والتقدم، ويشكل البحث العلمي العمود الفقري للجامعات ومؤسسات التعليم العالي، ولهذا خصصت الجامعات مراكز أبحاث متميزة ووضعت في تنظيمها الإدارية هيئات إدارية متخصصة في تنظيم شؤون البحث العلمي وتنسيقه ومتابعة تطويره ودعمه وذلك من خلال إنشاء العجادات والمعاهد المتخصصة للإدارة شؤون البحث العلمي . ( /http://www.alukah.net/culture/0/53460) وفي اقليم كوردستان يكنن الأستثمار في مجال الكليات والمعاهد ومراكز الدراسات السياحية والدراسات المهنة لأعداد كوادر سياحية تستهدف من ورائها تكوين كادر سياحي متخصص، أضافة المى البعثات والزمالات الدراسية، والتعاقد مع المنظات السياحية لغرض تدريب الكوادر وأستضافة الخبراء السياحيين للأستفادة من خبراتهم السياحية (البطاط والزويني، 2006: 321).

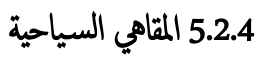
يزور السياح اقليم كوردستان العراق لأغراض مختلفة قد تكون سياسية أو أقتصادية أو أجتاعية أو ثقافية أو علمية، لذلك هناك بعض السياح يهتاجون الى المقاهي السياحية لتحقيق أهدافهم الخاصة للتنع بقضاء أوقات متتعة فيها، وتنتشر في محافظات الاقليم العديد من المقاهي الحديثة والقديمة، لذلك تعد هذه المقاهي فرصة أستثارية

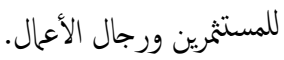


تشير معطيات الجدول (6) الى أن سبة المديرين من الفئة العمرية (اقل من 25) بلغت (9,71\%) وهذا يشير إلى ضعف اتسام معظم المديرين بالنضج الذهني، والرشد في أتخاذ القرارات، وبلغت نسبة الفئة العمرية (25-34)، (40,29\%) وهي أيضاً من الفئات التي تقع في مستويات منخفضة من النضج الذهني، أما الفئة العمرية (44-35) و (45-54) والفئة العمرية (55) فاكثر ، فقد بلغت نسبتا (33.50\%) ، (13.59 ) ) ، (2.91) على التوالي، ويشير ذلك أن المديرين في الفئات السابقة يتسمون بالنضج الفكري والحكمة في التصرف وأتخاذ القرارات، والتي من شأنها المساهمة في تعزيز الأستثمار في اقليم كوردستان العراق. 3.1.1.5 توزيع أفراد عينة الدراسة حسب التحصيل العلمي الجدول (7) توزيع أفراد عينة الدراسة حسب التحصيل العلي

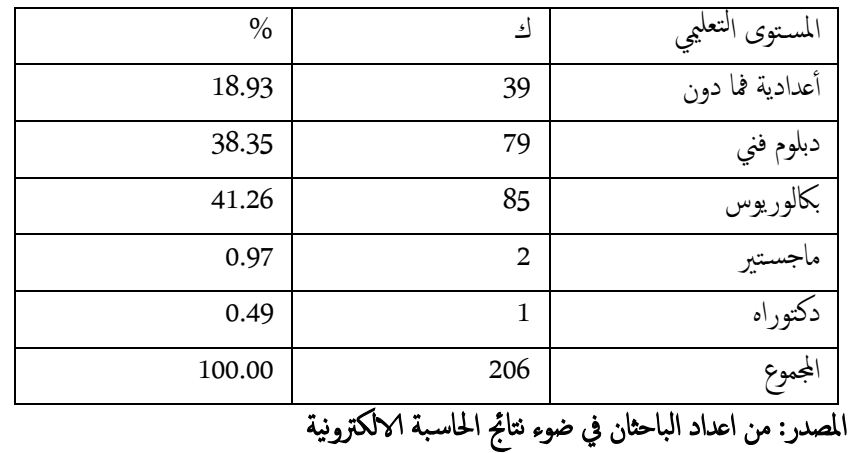

تشير معطيات الجدول (7) الى أن جميع المديرين يحملون مؤهلات أكاديية من الأعدادية والدبلوم الفني والبكلوريوس والماجستير والدكتوراه وبمعلات متباينة ويشير ذلك الم الدور الكبير لهؤلاء المديرين في تطوير منشاتهم، وايياد الحلول للمشكلات بطريقة علمية وأتخاذ القرارات المناسبة. 2.1.5 تحليل المعلومات المتعلقة بالاستثار السياحي. 1.2.1.5 ما هو رأيكم بواقع الأستثمار السياحي في اقليم كوردستان العراق تشير معطيات الجدول (8) الى أن نسبة الذين أشارو بأن الأستثمار في الاقليم جيد بلغ (8,74\%)، وبلغ نسبة الذين أشارو بعدم وجود تخطيط للأستثارات السياحية (23,30)، وبلغ نسبة الذين أشارو المى قلة المنشات السياحية (16,99\%)، وبلغ سبة الذين أشارو الى عدم ملائمة المنشات السياحية لحاجات ورغبات السياح (\%25,24)، وبلغ نسبة الذين أشارو الى قلة عدد شركات الادارة الفندقية ذات الخبرة العالمية (18,93\%)، وبلغ نسبة الذين أشارو الى تدني مستوى الخدمات السياحية وغياب الرقابة عليها (6,80\%).
الاقليم والمشاكل التي تعاني منها والسبل المناسبة لمعالجها. وقام الباحث بتوزيع (250) أستمارة على المديرين في المنشات السياحية في محافظات دهوك واربيل والسليمنية كالفنادق والمطاع والموتيلات، وبعد أستلام الأستبانات، وجد (206) أستارة صالحة للتحليل الاحصائي، وبمعل الاستجابة (82,4\%)، وستركز الدراسة الميدانية على تحليل اسئلة الأستبيان والتي ضّم إجابات (83) فندق، و (103) مطعم، و (20) موتيلا. وبموجب ما سبق سيتناول المبحث نتائج الدراسة الميدانية كتحليل المعلومات العامة للمديرين الذين تم أستطلاع ارأهم، وتحليل المعلومات المتعلة بالمنشات السياحية، والمعلومات المتعلقة بواقع الأستثمر السياحي في الاقليم، والمنافسة والتسويق والترويج السياحي، وتقييم دور كل من الحكومة والهيئة في تنشيط الطلب السياحي، وكذلك تلك تقييم الدور الأقتصادي والأجتاعي للسياحة في الاقليم.

1.1.5 ت تحليل المعلومات العامة 1.1.1.5 توزيع أفراد عينة الدراسة حسب الجنس المعام المعاد الجدول (5) توزيع أفراد عينة الدراسة حسب الجنس الجنس

\begin{tabular}{|c|c|c|}
\hline$\%$ & s) & الجنس \\
\hline 81.07 & 167 & ذكر \\
\hline 18.93 & 39 & أنثى \\
\hline 100.00 & 206 & المجموو \\
\hline
\end{tabular}

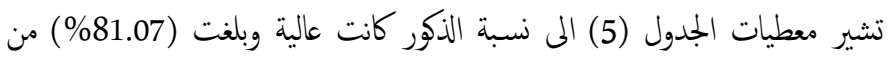
الأفراد المبحوثين مقارنة بنسبة الاناث التي بلغت (18.93\%) من الأفراد المبحوثين، مما يشير الى أن معظم مدراء المنشات السياحية من الذكور، وهي حالة طبيعية اذ أن الاناث لا يرغبون العمل في هذه المنشات، أو قد يعود السبب الى الطبيعة الأجتاعية للاقليم الذي لا يسمح للاناث بالعمل في هذه المنشات. - 2.1.1.5 توزيع أفراد عينة الدراسة حسب العمر الجدول (6) توزيع أفراد عينة الدراسة حسب العر

\begin{tabular}{|c|c|c|}
\hline$\%$ & ك & العمر \\
\hline 9.71 & 20 & أقل من 25 \\
\hline 40.29 & 83 & $34-25$ \\
\hline 33.50 & 69 & $44-35$ \\
\hline 13.59 & 28 & $54-45$ \\
\hline 2.91 & 6 & 55 فاكُر \\
\hline $100.00 \%$ & 206 & المجموع \\
\hline
\end{tabular}


ب. مؤشر أجتاعي، حيث يكون الفرد قد تعلم في المنشات الأخرى التي عمل فهيا

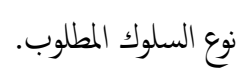
ت. إن نوعية الخبرة التي حصل عليها الفرد معمة لأغراض الترقية في المستقبل، فطول الفتزة الزمنية التي خدما الفرد ليست مبررا قوياً لترقيته بقدر نوع العمل الذي مارسه الفرد طيلة حياته.

يليهم الذين فضلوا الأستثمار في قطاع السياحة لكونه قطاع واعد، وجاء بنسبة مئوية بلغت (31.46\%)، ثم الذين فضلوا الأستثمار في قطاع السياحة لكون الأستثمار فيه ملائم جدا، اذ جاء بنسبة مئوية بلغت (16.85\%)، وبلغت أقل نسبة (1.12\%)، ويشير ذلك الى ضعف التسهيلات والحوافز في القطاع السياحي مقارنة بالقطاعات

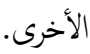

\subsubsection{5 هل أن التسهيلات والحوافز التي تقدما حكومة الاقليم لتشجيع الأستثار} الجدول (10) التسهيلات والحوافز التي تثدما حكومة الاقليم لتشجيع الأستثار

\begin{tabular}{|c|c|c|}
\hline$\%$ & ك & التسهيلات والحوافز \\
\hline 0.49 & 1 & ل ميتازة \\
\hline 14.08 & 29 & جيدة \\
\hline 46.12 & 95 & متوسطة \\
\hline 39.32 & 81 & غير مشجعة \\
\hline 100.00 & 206 & المجموع \\
\hline
\end{tabular}
تشير معطيات الجدول (10) الى أن (46.12\%) من مديري المنشات السياحية أشاروا الى أن التسهيلات والحوافز التي تقدما حكومة الاقليم لتشجيع الأستثار السياحي متوسطة. ويعزو الباحثان هذه النتيجة أن المستثمرون يرغبون في تحقيق أكبر عائد مككن من أستثمار أمواله في، لذا فأنه قبل الشروع في الأستثمار يقوم بدراسة تكلفة كل مشروع ويقوم بالموازنة مابين العائد الذي يحصل عليه وبين الخخاطر والصعوبات التي يتحملها في سبيل الحصول على هذا العائد، وأن أهم عناصر الموازنة التي توثثر تاثيراً مباشراً في عوائد الأستثمار هي الحوافز التسهيلات والحوافز، لذا ينبغي على حكومة الاقليم حتى تحافظ على ايراداتها الضريبة من الضياع وفي نفس الوقت الحفاظ على المشاريع الأستثمرية أن تتوخى قدر المستطاع تحقيق التوقعات المشروعة للمستثمر وأن تكون
الجدول (8) واقع الأستثار السياحي في الاقليم

\begin{tabular}{|c|c|c|}
\hline$\%$ & ك & 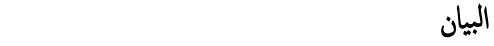 \\
\hline 8,74 & 18 & 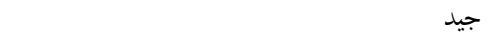 \\
\hline 23,30 & 48 & 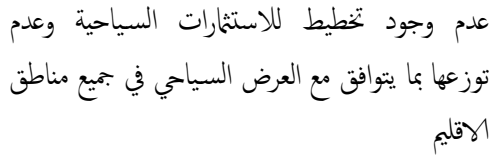 \\
\hline 16,99 & 35 & قلة عدد المنشات السياحية التي تستقبل السياح \\
\hline 25,24 & 52 & 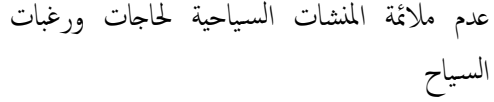 \\
\hline 18,93 & 39 & قلة عدد شركات الادارة الفندقية ذات الخبرة العلمية \\
\hline 6,80 & 14 & تدني مستوى الخدمات السياحية وغياب الرقابة عليها \\
\hline 100,00 & 206 & المجموع \\
\hline
\end{tabular}
الجدول (9) أسباب أختيار قطاع السياحة للأستثار

\begin{tabular}{|c|c|c|}
\hline$\%$ & s) & 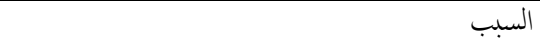 \\
\hline 31.46 & 84 & قطاع السياحة واعد \\
\hline 11.24 & 30 & المنافسة في قطاع السياحة قليلة \\
\hline 16.85 & 45 & الاستثمار في القطاع السياحي ملائ جدا \\
\hline 32.96 & 88 & عدم توفر الخبرة الكافية في قطاعات اخرى \\
\hline 1.12 & 3 & $\begin{array}{r}\text { كثرة التسهيلات والحوافز في القطاع السياحي مقارنة } \\
\text { بالقطاعات الاخرى }\end{array}$ \\
\hline 5.28 & 17 & العرض السياحي المتوفر بالقرب من المنشاة \\
\hline 100.00 & 062 & المجموع \\
\hline
\end{tabular}

المصدر: من اعداد الباحثان في ضوء نتاجُج الحاسبة الكلكتونية تشير معطيات الجدول (9) الى أن (32.96\%) من مديري المنشات السياحية فضلوا الأستثمار في قطاع السياحة بدلا من قطاع اخر بسبب عدم توفر الخبرة الكلفية لديهم في قطاعات أخرى من الأقتصاد الوطني. ويعزو الباحث هذه النتيجة المى أن لخبرة الادارة والعاملين دور مم في تحقيق المنشاة لأهدافها، لذلك فان عدم أمتلاك الفرد للخبرة في قطاع معين قد يكلفه الكثير من الخنسارة والسمعة وأرتفاع التكليف، ومن ثخ غلق المنشاة. ويثير (المغربي، 2004: 164) أن للخبرة تأثير كير في أداء الفرد والمنشاة على حد

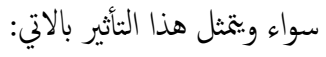
أ. خفض النكلة والوقت الذي يتعلق بالندريب. 
تشير معطيات الجدول (12) الى أن (66.99\%) من المديرين أقروا الأستثظر في قطاع السياحي بسبب الطلب السياحي الكبير في الاقليم. ويعزو الباحث هذه النتيجة أن زيادة الطلب السياحي هو تعبير عن أتجاهات السياح لشراء منتج سياحي معين، أو زيارة منطقة معينة، قوامه مزيج مركب من عناصر مختلفة تمثل الدوافع والرغبات والقدرات والحاجات الشخصية التي يتأثر بها المستهلكون السياحيون من حيث أتجاهات الطلب على منطقة معينة، ويحقق زيادة الطلب السياحي الأهداف التي تسعى المنشأة الى تحقيقها، ومن هنا جاءت أهتمام المديرين بالطلب السياحي في الاقليم والتي شكلت معدل كير في أستجاباتهم. وأشار (17.70\%) بأن قرار الأستثمار جاء بسبب التشريعات والتسهيلات الحكومية المشجعة، وأشار (9.57\%) بأن قرار الأستثمار جاء بسبب مقارنة الجدوى الأقتصادية

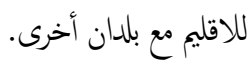

\subsubsection{5 ما هي المشاريع السياحية التي تفضلون أقامتها مستقبلا في الاقليم؟} الجدول ( 13) المشاريع السياحية التي يضضل المستثر أقامتها مستقبلا

\begin{tabular}{|c|c|c|}
\hline$\%$ & ك & المشاريع السياحية المستقبلية \\
\hline 47.09 & 97 & مدينة سياحية \\
\hline 21.36 & 44 & فندق \\
\hline 17.96 & 37 & مطعم \\
\hline 11.65 & 24 & كافيتيريا \\
\hline 1.94 & 4 & أخرى \\
\hline 100.00 & 206 & الجمجوو \\
\hline
\end{tabular}

المصدر: من اعداد الباحثان في ضوء نتائج الحاسبة الكلكتونية

تشير معطيات الجدول (13) الى أن (47.09\%) من المديرين يفضلون أن تكون

$$
\text { مشاريعهم المستقبلية مدن سياحية. }
$$

ويعزو الباحث رغبة المديرين في اقليم كوردستان بتفضيل أقامة مدن سياحية بدلا من منشأت ايواء أخرى، وذلك لدور المدن السياحية في توفير الراحة والأستجام والتزفية للسياح، كما أنه يعد من المشروعات المهمة والتي يساهم في تحسين الوضع الأقتصادي للمستثمرين والاقليم، فضلا عن دورها في توفير عشرات فرص عمل مباشرة وأخرى غير مباشرة ، يليهم الذين يرغبون أن تكون مشاريعهم المستقبلية فنادق، اذ جاء بنسبة مئوية بلغت (21.36\%)، ثم الذين يفضلون أن تكون مشاريعه المستقبلية
هناك دراسة وافية عند منح الحوافز والتسهيلات وتكلنها ومدى أهمية المشروع الاستثماري، ومن ثم أتخاذ القرار بقبول أو رفض المشروع الاستثماري. ويشير (39.32\%) من هؤلاء المديرين بان التسهيلات والحوافز غير مشجعة، ويشير (14.08\%)، من المديرين بأن التسهيلات والحوافز جيدة، فيا أشار (0.49\%) منهم بأن التسهيلات والحوافز ممتازة، وهي نسبة قليلة جدا، وتشير النتائُ السابقة الى أن التسهيلات والحوافز التي تقدها حكومة الاقليم ضعيفة اذ بلغت المعدل العام

\subsubsection{5 اجراءات الحصول على ترخيص لمنشآة سياحية في الاقليم؟}

\begin{tabular}{|c|c|c|}
\hline$\%$ & ك & اجراءات الترخيص \\
\hline 20.93 & 45 & أمر معقد ويستغرق وقتا وبجدا كيرا \\
\hline 36.74 & 79 & أمر سهل جدا ويستغرق فترة زمنية قصيرة \\
\hline 42.33 & 91 & يجتاج لتعديل في التشريعات والأسلوب \\
\hline 100.00 & 215 & المجموع \\
\hline
\end{tabular}
الجدول (11) اجراءات الحصول على ترخيص للمنشأة السياحية

تشير معطيات الجدول (11) الى أن (42.33\%) من المديرين أشاروا بأن اجراءات الحصول على ترخيص للمنشأة السياحية يحتاج لتعديل في التشريعات والأسلوب، وأشارو (36.74\%) من المديرين بان الاجراءات سهلة جدا ولا يستغرق سوى فتزة زمنية قصيرة، فيا أشارو (20.93\%) من هؤلاء المديرين بأن الاجراءات معقدة ويستغرق وقتا وبجدا كبيرا. وتشير النتائُ السابقة على أن اجراءات الحصول على تلى التزخيص لمنشأة سياحية ضعيفة جدا، اذ بلغ المعدل العام (33,33\%). 5.2.1.5 يعود قرار الأستثار في قطاع السياحة بدلا من قطاع اخر المى؟

\begin{tabular}{|c|c|c|}
\hline$\%$ & ك & قرار الاستثظر \\
\hline 5.74 & 12 & الدء المباشر من قبل حكومة الاقليم والهيئة العامة للسياحة فيه \\
\hline 17.70 & 37 & التشريعات والتسهيلات الحكومية المشجعة \\
\hline 66.99 & 140 & الطلب السياحي الكبير في الأقليم \\
\hline 9.57 & 20 & دراسة الجدوى الاقتصادية لعدة بلدان \\
\hline 100.00 & 209 & 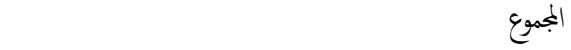 \\
\hline
\end{tabular}
الجدول (12) قرار الأستثار في قطاع السياحة بدلا من قطاع اخر 
بالقرب من المعابر الحدودية، وبلغت أقل نسبة (3.08\%)، وهم الذين يفضلون أقامة مشاريعهم بالقرب من عروض سياحية أخرى.

الجدول (15) العروض السياحة لاقامة المشروع السياحي

\begin{tabular}{|c|c|c|}
\hline$\%$ & ك & لعروض السياحية \\
\hline 14.10 & 32 & لمدن التأريخية والقديمة \\
\hline 7.05 & 16 & لمواقع الأثرية \\
\hline 26.87 & 61 & المناطق الجبلية المميزة \\
\hline 29.07 & 66 & بالقرب من الطرق الدولية \\
\hline 19.82 & 45 & القرب من المعابر الحدودية \\
\hline 3.08 & 7 & عروض سياحية أخرى تذكر \\
\hline 100.00 & 227 & لمجموع \\
\hline
\end{tabular}

9.2.1.5 ما هو التصنيف السياحي الني تريدونه لمشاريعك السياحية التي ترغبون

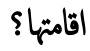

الجدول (16) التصنيف السياحي المرغوب

\begin{tabular}{|c|c|c|}
\hline$\%$ & ك & التصنيف السياحي \\
\hline 45.63 & 94 & خمس نجوم \\
\hline 20.39 & 42 & اربع نجوم \\
\hline 16.99 & 35 & ثلاث نجوم \\
\hline 6.80 & 14 & نجمتين \\
\hline 2.91 & 6 & نجمة واحدة \\
\hline 7.28 & 15 & شعبي \\
\hline 100.00 & 206 & المجموع \\
\hline
\end{tabular}

المصدر: من اعداد الباحثان في ضوء نتائج الحاسبة الالكتونية

تشير معطيات الجدول (16) الى أن (45.63\%) من المديرين يفضلون أن تكون مشاريعهم السياحية ذات خمس نجوم، ويفضل (20.39\%) من المديرين أن تكون مشاريعهم السياحية ذات أربع نجوم، يليه المشاريع ذات الثلاث نجوم وبنسبة بلغت (16.99\%)، يليه المشاريع ذات النجمتين وبنسبة بلغت (6.80\%)، يليه المشاريع السياحية الشعبية وبنسبة بلغت (7.28\%)، واخيرا المشاريع ذات النجمة الواحدة

$$
\text { وبنسبة (2.91\%). }
$$

ويعزو الباحث نتيجة تفضيل مديري المنشات السياحية لفنادق المنس بسبب كون هذا النوع من الفنادق تعد من أرقى أنواع الفنادق الموجودة في العالم، وتقدم خدمات متكاملة للمستهاكين وبأسعار مرتفعة تتناسب مع نوع هذه الخدمات المتقدمة، ولها مواصفات متميزة من حيث الموقع والغرف والأغذية والمشروبات، أما فنادق الأربع نجوم
مطعم وكافتريا ومشاريع أخرى، وجاءت بنسب مئوية بلغت (17.96\%)، . (\%1.94) ، (\%11.65)

7.2.1.5 ماهي العوامل التي تأخذونها في الأعتبار عند تحديد مكان أقامة المثروع

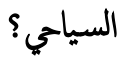

تشير معطيات الجدول (14) الى أن (40.19\%) من المديرين يأخذون البنية التحتية بنظر الأعتبار عند أقامة مشاريعهم السياحية.

الجدول (14) العوامل التي يأخذها المستثر عند أقامة المشروع السياحي

\begin{tabular}{|c|c|c|}
\hline$\%$ & ك & عوامل اقامة المثروع السياحي \\
\hline 21.50 & 46 & داخل المدن \\
\hline 12.62 & 27 & على أطراف المدن \\
\hline 0.93 & 2 & ل \\
\hline 40.19 & 86 & توفر البنية التحتية \\
\hline 21.03 & 45 & قربها من اماكن العرض السياحي \\
\hline 1.87 & 4 & جحم الطلب السياحي \\
\hline 871. & 4 & قربها أو بعدها من مشاريع أخرى منافسة \\
\hline 100.00 & 214 & المجموع (المجو \\
\hline
\end{tabular}

ويعزو الباحث نتائج الجدول (14 ) الى أن المديرين الذين تم أستطلاع ارائهم يعلمون تماما الدور المهم للبنية التحتية، اذ تعد من أهم الدعائم الرئيسية التي ستحفز إنشاء صناعة سياحية قادرة على جذب أستثارات متنوعة، ويتطلب الأمر ليس تهيئة البنية التحتية فقط، بل توفير كافة الخدمات، بأعتبار أن السياحة بمحوعة من الخدمات المترابطة ببعضها البعض، الأمر الذي يتطلب توفيرها لتحقيق العمل التكاملي فيا بنها، فعندما تتوفر تلك الخدمات نصل المى مرحلة الإيواء التي تشدد على أن يكون لدى السائُ العديد من الحيارات المطروحة أماهه، سواء كان نوعية السكن أو درجة مستواه أو قيمنه المالية التي تشمل جميع الشرائح ، ويفضل (21.50\%) من المديرين أن تكون مشاريعهم داخل المدن، ويفضل (21.03\%) منهم أن تكون مشاريعهم بالقرب من أماكن العرض السياحي، وبلغت أقل نسبة (0.93\%)، وهم الذين يفضلون أقامة مشاريعهم في القرى والأرياف.

\subsubsection{5 ما هي العروض السياحية التي تفضلون اقامة مشروعكم السياحي بقرها؟} تشير معطيات الجدول (15) الى أن (29.07\%) من المديرين يفضلون أن تكون مشاريعهم السياحية بالقرب من الطرق الدولية، ويضضل (26.87\%) منهم أن تكون مشاريعهم في المناطق الجبلية المتميزة، ويفضل (19.82\%) منهم أن تكون مشاريعهم 
أن تصميم وتسويق المنتجات أو المذدمات أو الأفكار التي تشبع حاجات العملاء هو القاعدة أو الأساس لخلق المنافع، والتسويق يعتبر أستراتيجية مهمة جدا لكل من المنشأة والفرد وهذا ينعكس بدوره على الأقتصاد بشكل عام، كما يشمل التزويج جميع نشاطات الأتصال مع الزبائن للناثير فيهم لشراء منتجات المنشأة كالأعلانات، العلاقات العامة، ترويج المبيعات، البريد المباشر، و يتدخل الترويج في جميع ما سبق ذكره من العناصر فيثلاً يتدخل في شكل المنتج و ججمه. كما أن كافة مصروفات الترويج يجب أن تكون مشمولة في عملية تحديد السعر بالاضافة إلى أن مكان الترويج له أهمية بالغة في

وأشار (35.54\%) من المديرين بأن وجود يساعد على تحقيق مزيد من المبيعات والأرباح، وأنشار (21.69\%) من المديرين بأن القسم يتولى همة القيام بالأبحاث التسويقية، وأشار (3.61\%) من المديرين بأن القسم لا يتولى همة القيام بالأبحاث التسويقية، بينها أشار (2.41\%) من المديرين بأنه لا جدوى لوجود هذا القسم في المنشاة السياحية.

3.3.1.5 الأساليب التسويقية والترويية السياحية التي تقوم بها وزارة السياحة والبلديات والهيئة العامة للسياحة الجدول (19) الأساليب التسويقية والترويية السياحية التي تقوم بها الحكومة

\begin{tabular}{|c|c|c|}
\hline$\%$ & ك & الأساليب التسويقية والترويية السياحية \\
\hline 0.00 & 0 & متمتازة \\
\hline 6.80 & 14 & جيدة \\
\hline 34.95 & 72 & متوسطة \\
\hline 58.25 & 120 & ضعيفة \\
\hline 100.00 & 206 & البجموع \\
\hline
\end{tabular}

تشير معطيات الجدول (19) الى أن (58.25\%) من المديرين أثشارو بأن الأساليب التسويقية والترويجية السياحية التي تقوم بها الحكومة ضعيفة، وأشار (34.95\%) بأن الأساليب متوسطة، فيا أشار (6.80\%) بأن الأساليب جيدة.

4.3.1.5 يعود وجود تقصير في التسويق والترويج السياحي في الاقليم المى تشير معطيات الجدول (20) الى أن (26.02\%) منهم أشارو بأن أسباب ضعف التسويق والترويج السياحي في الاقليم يعود الى تقصير حكوي، وأنشار (25.20\%) منهم بأن الأسباب يعود الى قلة الخبرة والكفاءة في مجال التسويق والتوويج السياحي، وأشار (23.17\%) منهم بأن الأسباب يعود الى غياب أستراتيجية مشتركة بين
هي الأخرى تقدم خدمات راقية وبشكل متكمل وأسعارها تكون أقل من أسعار الفنادق ذات المّس نجوم، وأصبحت السياحة منذ فترة ليست بالقليلة، أحد أهم الموارد المالية خاصة من النقد الأجنبي، وتعد المنشات الفندقية بوجه عام والخدمة الفندقية في المطائ بوجه خاص أحد أهم تلك الموارد سواء لصناعة السياحة والفنادق عموما أو لدخل الفندق أو المنشأة السياحية على وجه الخصوص، إن السياحة سواء الداخلية أو الخارجية تعتمد أعتماديرا على المنشات السياحية الأخرى والمكملة لصناعة الفنادق وتأتي على رأسها المطاع. 3.1.5 التسويق والتوويج السياحي في الاقليم وسبل تحسين أدائه 1.3.1.5 هل يوجد في منشأتكم قسم خاص بالتسويق والتوميج السياحي؟ تشير معطيات الجدول (17) الى أن (65.05\%) من المديرين أشارو بأنه لا يوجد قسم متخصص بالتسويق والترويج السياحي في منشاتهم، فيا أشار (34.95\%) من المديرين بأنه يوجد قسم متخصص بالتسويق والترويج السياحي في منشاتهم الجدول (17) وجود قسم متخصص بالتسويق والتويع السياحي

\begin{tabular}{|c|c|c|}
\hline$\%$ & ك & الجواب \\
\hline 34.95 & 72 & يوجد \\
\hline 65.05 & 134 & لا يوجد \\
\hline 100.00 & 206 & الجمموع \\
\hline
\end{tabular}

2.3.1.5 في حالة يوجد لديكم قسم خاص بالتسويق والترويج السياحي فهل؟ الجدول (18) مهام وجود قسم متخصص بالتسويق والترويج السياحي

\begin{tabular}{|c|c|c|}
\hline$\%$ & ك & مهام القسم \\
\hline 21.69 & 36 & يقوم هذا القسم بالأبحاث التسويقية \\
\hline 3.61 & 6 & لا يقوم هذا القسم بالأبحاث التسويقية \\
\hline 35.54 & 59 & يساعد القسم على تحقيق مزيد من المبيعات والأرباح \\
\hline 2.41 & 4 & لا جدوى لوجود هذا القسم \\
\hline 36.75 & 61 & انصح بوجود هذا القسم في كل منظمة سياحية \\
\hline 100.00 & 166 & المجموع \\
\hline
\end{tabular}

تشير معطيات الجدول (18) الى أن (36.75\%) من المديرين ينصحون بوجود قسم متخصص بالتسويق والترويج السياحي في كل منشاة سياحية. ويعزو الباحث هذه النتيجة الى أن التسويق يعتبر أحد أهم الأنشطة التي تقوم بها المنشات الحديثة والتي تقوم على ايجاد أو خلق المنافع لضمان الأستمرار لأي منشآة، كما 
4.1.5 تقييم التجربة المكومية في تفعيل الأستثار السياحي في الاقليم 1.4.1.5 في حال ترون أن ملثقيات الأستثار السياحي التي تعقدها وزارة البلديات

والسياحة والهيئة العامة للسياحة في الاقليم بحاجة لتطوير فهل هذا يعود الى الجدول ( 22 ) تثييم التجربة المكومية في تفعيل الأستثار السياحي في الاقليم

\begin{tabular}{|c|c|c|}
\hline$\%$ & ك & الابسباب \\
\hline 13.87 & 33 & ضعف ادارة المؤتمرات \\
\hline 42.86 & 102 & لا يرافقها حملة اعلامية مناسبة \\
\hline 9.66 & 23 & ضعف الجدوى الاقتصادية للمشاريع المعروضة \\
\hline 11.34 & 27 & صيغة الأستثمار المعروض ومدتها لا تناسبكم \\
\hline 6.72 & 16 & معظم المشاريع المعروضة بحاجة لرأسمال كير جدا \\
\hline 6.72 & 16 & التعاقد على المشاريع المعروضة مليء بالروتين \\
\hline 8.82 & 21 & المشاريع المعروضة لا تغطي جميع مناطق الاقليم \\
\hline 100.00 & 238 & المجموع \\
\hline
\end{tabular}

المصدر: من اعداد الباحثان في ضوء نتاجُ الحاسبة الكلكترونية

تشير معطيات الجدول ( 22) الى أن (42.86\%) من المديرين أشارو بأن ملتقيات الأستثار السياحي التي تعقدها وزارة البلديات والسياحة والهيئة العامة للسياحة في الاقليم بحاجة الى التطوير لأنه لا يرافقها حملة اعلامية مناسبة، وأشار (13.87\%) منهم بأن السبب يعود المى ضعف ادارة المؤمرات، وأشار (11.34\%) بأن السبب يعود الى صيغة الأستثار المعروض ومدتها غير المناسبة، وبلغت اقل نسبة (\%6.72)، (6.72)، والذين أشارو بأن السبب يعود الى أن معظم المشاريع المعروضة بحاجة لرأسمال كير جدا، وان التعاقد على المشاريع المعروضة مليء بالروتين. 2.4.1.5 ما هو تثيهم للدور اللذي تقوم به الهيئة العامة للسياحة في تنشيط الطلب والأستثار السياحي. الجدول ( 23 ) دور الهيثة العامة للسياحة في تنشيط الطلب السياحي والأستثار السياحي

\begin{tabular}{|c|c|c|}
\hline$\%$ & ك & الدرجة \\
\hline 0.00 & 0 & ميتناز \\
\hline 12.62 & 26 & جيد \\
\hline 36.41 & 75 & متوسط \\
\hline 50.97 & 105 & ضعيف \\
\hline 100.00 & 206 & الجمموع \\
\hline
\end{tabular}

القطاعين العام والخاص، وبلغت أقل نسبة (1.63\%)، وهم الذين أشار بأن الضعف

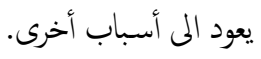

الجدول (20) أسباب ضعف التسويق والتويج السياحي في الهليم

\begin{tabular}{|c|c|c|}
\hline$\%$ & ك & الأسباب \\
\hline 26.02 & 64 & تقصير حكوي في هذا المجال \\
\hline 19.11 & 47 & ضعف دور الوزارة والهيئة العامة للسياحة \\
\hline 23.17 & 57 & غياب استراتيجية مشتركة بين القطاعين العام والخاص \\
\hline 25.20 & 62 & قلة الخبرة والكفاءة في مجال التسويق والتزويج السياحي \\
\hline 4.88 & 12 & عدم وجود حاجة للتسويق والترويج السياحي \\
\hline 1.63 & 4 & أسباب أخرى تذكر \\
\hline 100.00 & 246 & البمموع \\
\hline
\end{tabular}

5.3.1.5 رتب الوسائل التويية التالية بحسب أهيتها من وبجة نظرك من منية الجدول (21) الوسائل الترويية حسب أهميتها

\begin{tabular}{|c|c|c|}
\hline$\%$ & ك & الوسائل الترويجية \\
\hline 48.54 & 100 & المشاركة في المعارض السياحية الدولية \\
\hline 9.22 & 19 & دعوة وفود عالمية لزيارة الاقليم \\
\hline 5.34 & 11 & دعوة نجوم الفن والمشاهير لزيارة الاقليم \\
\hline 6.80 & 14 & دعوة الادباء والكتاب العالمين لزيارة الاقليم \\
\hline 22.82 & 47 & القيام بالاعلانات السياحية في التلفزيونات العالمية \\
\hline 7.28 & 15 & اقامة المباريات الرياضية بين فرق عالمية \\
\hline 100.00 & 206 & المجموع \\
\hline
\end{tabular}

المصدر: من اعداد الباحثان في ضوء نتاجُ الحاسبة الهلكتونية

تشير معطيات الجدول (21) الى أن ترتيب الوسائل الترويجية جاءت على النحو الاتي:

O المشاركة في المعارض السياحية الدولية جاءت بنسبة (48.54\%). O القيام بالأعلانات السياحية في التلفزيونات العالمية جاءت بنسبة (22.82\%). O دعوة وفود عالمية لزيارة الاقليم جاءت بنسبة (9.22\%). O اقامة المباريات الرياضية بين فرق عالمية جاءت بنسبة (7.28\%). O دعوة الأدباء والكتاب العالمبن لزيارة الاقليم جاءت بنسبة (6.80\%). O دعوة نجوم الفن والمشاهير لزيارة الاقليم جاءت بنسبة (5.34\%). 
تضييق حجم القطاعات السوقية المستهدفة والاتجاه نخو التسويق، فإن العديد من المنشات سارعت إلى تبني وسيلة جديدة في الترويج وهي التسويق المباش، هو نظام أتصال تفاعلي في مجال التسويق، يضمن أستخدام بمموعة من الوسائل غير التقليدية، والتي تحقق أستجابة ملموسة بأقل بجد منكن، ويتميز بالمرونة، والدقة في أختيار المستهلكين واقناعهم. وأشار (21.29) من المديرين أن ضعف مساهمة الهيئة العامة للسياحة في تنشيط

$$
\text { الطلب السياحي يعود الى ضعف البنية التنظيمية لها. }
$$

ويعزو الباحث هذه النتيجة الى أن البنية التنظيمية يعبر عن علاقات العمل في المنشاة كونه يمثل الإطار العام للعلاقات التنسيقية فيها والوسيلة الفعالة في تحقيق أهداف رك المنظمة ومواجتها للظروف البيئة المحيطة ، وهناك نوعين من البنية التنظيمة، الطويل ويكون عدد طبقات المديرين كثيرة مما يجعل عملية اتخاذ القرارات بطيئة، والقصير وهذا النوع يعطي مسئوليات وتفويض أكثر للمديرين مما يزيد من سرعة أتخاذ القرارات، في الوقت نفه فإن كل مدير يكون مسئولا عن عدد أكبر من المرؤوسين، مما يساهم بشكل كير في تحقيق المنظمة لأهدافها. وأثار (15.84\%) من المديرين بأن ضعف مساهمة الهيئة تعود الى فشل اداراتها في رسم أستراتيجية هادفة للقطاع السياحي الخاص في الاقليم، وبلغت أقل نسبة (1.49\%)، والذين أثشارو بأن سبب ضعف الهيئة يعود الى أسباب أخرى. 5.1.5 تثييم الدور الأقتصادي والأجتاعي للقطاع السياحي في الاقليم 1.5.1.5 هل تؤيد مبدأ الشراكة في الأستثار ما بين القطاع العام والخاص الجدول (25) مبدأ الشراكة ما بين القطاع العام والماص

\begin{tabular}{|r|r|r|}
\hline$\%$ & ن & \\
\hline 65.05 & 134 & \\
\hline 34.95 & 72 & \\
\hline 100.00 & 206 & \\
\hline
\end{tabular}

تشير معطيات الجدول (25) الى أن (65.05\%) من المديرين الذين تم أستطلاع ارائهم أشارو بأهم يؤيدون مبدأ الشراكة في الأستثمار ما بين القطاع العام والخاص. ويعزو الباحث هذه النتيجة بأن الشراكة الاستثارية علاقة تجمع ما بين طرفين أو

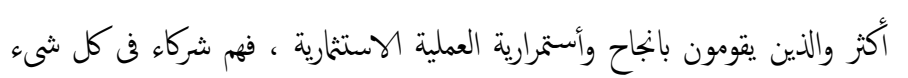

تشير نتاجُج الجدول(23) الى أن (50.97\%) منهم أشارو بأن دور الهيئة العامة في تنشيط الطلب والأستثمار السياحي ضعيف، وأشار (36.41\%)منم الى أن الدور متوسط، وأشار (12.62\%) بأن الدور جيد.

3.4.1.5 في حال ترون أن مساهة الهيئة العامة للسياحة في تنشيط الطلب ضعيف، فهل هذا يعود الى لي

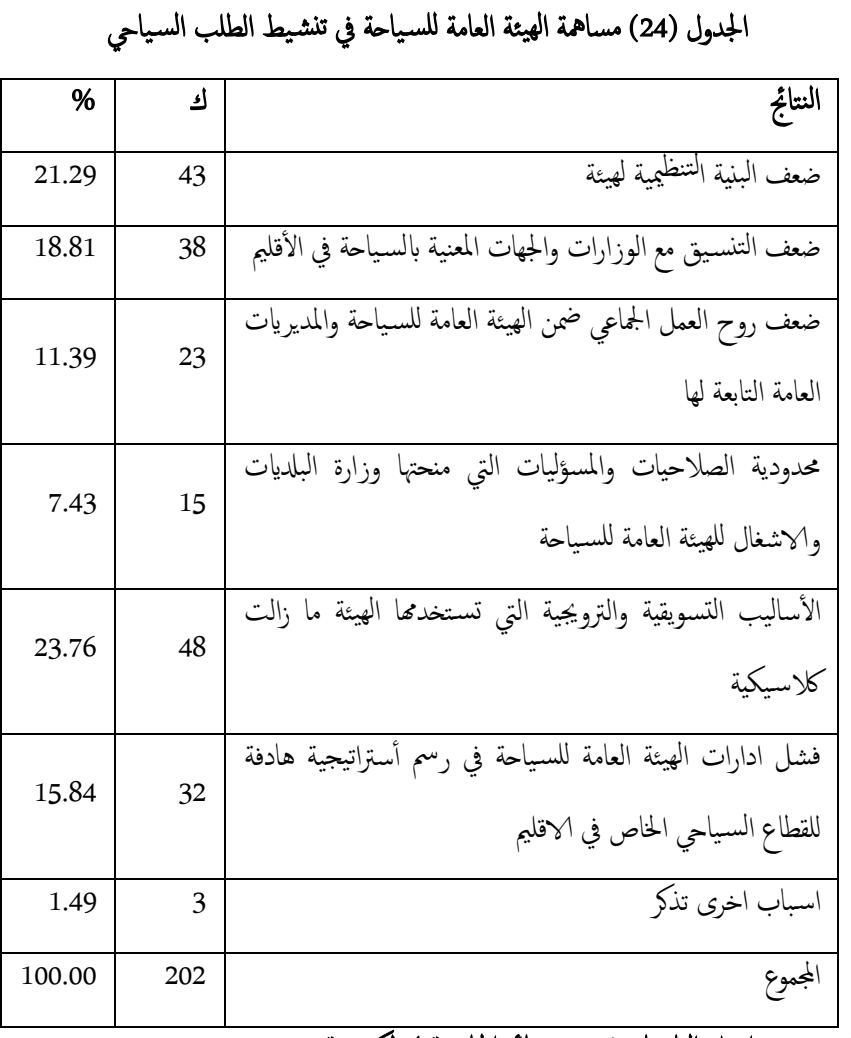

المصدر: من اعداد الباحثان في ضوء نتائج الحاسبة الكلكتونية

تشير معطيات الجدول (24) الى أن (23.76\%) من المديرين يؤكدون بأن ضعف موسف مساهمة مساهمة الهيئة العامة للسياحة في تنشيط الطلب السياحي يعود الى أن الأساليب التسويقية والترويية التي تستخدما الهيئة ما زالت كلاسيكية وغير فعالة. ويعزو الباحث هذه النتيجة بأن الأساليب التسويقية والترويية تمثل المراة العكسة للمنشات السياحية، فن خلاله تتفاعل المنشاة مع بيئتها الخارجية بواسطة أدوات عديدة لكل واحدة منها خصائصها المميزة، ويؤدي الترويج وظيفة رئيسية هي إخبار واقناع والثاثثير على المستهلكين الحاليين والمحتلين لتبني موقف ايجابي اتجاه الرسالة التزويية وما تعرضه، واذا ما فهم المستهلك الرسالة الترويية بنفس المعنى الذي قصده المرسل، فإن التزويج سيكون قد حقق هدف، لقد ظلت الأدوات الترويية المعروفة نابحة في إطار التسويق، ونظرا لاستهاف أستهداف أسواق كبيرة، وتزايد الاتجاه نو 
ومن ثخ فهم يتقاسمون الربح والحسارة على حد سواء، ولذلك لا بد أن تكون هناك الى (540410) سائ، وأنخض هذا العدد خلال فصل الصيف ليصل الى جوانب ايهابية في عملية الأستثار، اذ أن الشراكة توفر السيولة المادية اللازمة لبدء (214573)، وأزاد هذا العدد خلال فصل الخريف ليصل الى (248373) سائ، عملية الاستثمر، وكذلك الحصول على الخبرات والمهارات المتنوعة، وخلق ادارة أكثر وتؤكد النتأُ صحة الفرضية أعلاه والتي تشير الى أن الطلب السياحي في اقليم كفاءة وفاعلية، كما أنه في وجود خسارة فان مختلف الأطراف سوف تتحمل المسؤولة، كوردستان يتميز بالموسمية.

الجدول (26) الطلب السياحي حسب فصول السنة خلال الفترة (2014-2013) مترك

\begin{tabular}{|c|c|c|c|}
\hline 2014 & 2013 & الاشهر & الفصل \\
\hline 203168 & 192396 & كانون الثاني & \multirow{3}{*}{ الشتاء } \\
\hline 190916 & 177680 & شباط & \\
\hline 181783 & 213800 & اذار & \\
\hline 575867 & 583876 & & المجموع \\
\hline 205098 & 176928 & ن ليسان & \multirow{3}{*}{ الربيع } \\
\hline 170120 & 201307 & مايس & \\
\hline 165192 & 330882 & حزيران & \\
\hline 540410 & 709117 & & المجموع \\
\hline 69862 & 187707 & تموز & \multirow[t]{3}{*}{ الصيف } \\
\hline 84285 & 519578 & اب & \\
\hline 60426 & 271247 & ايلول & \\
\hline 214573 & 978532 & & المجموع \\
\hline 64466 & 285661 & ت الاول & \multirow{3}{*}{ الخزيف } \\
\hline 114027 & 212438 & ت الثاني & \\
\hline 69880 & 186112 & كـ الاول & \\
\hline 248373 & 684211 & & المجموع \\
\hline
\end{tabular}

3.6 يتباين الطلب السياحي في اقليم كوردستان العراق حسب أماكن الاقامة.

تشير نناجُج الحاسبة الكلكتونية بأن هناك تباين في الطلب السياحي في الاقليم حسب أماكن القدوم، اذ بلغ بموع عدد السياح من داخل الاقليم خلال الفنزة (2013-2007)، (2,27,973)، وبلغ مجموع عدد السياح من خارج الاقليم خلال نفس الفتزة (7,265,295)، فيها بلغ مجموع عدد السياح من الأجانب خلال نفس الفتزة (1,949,019)، وتؤكد النتأُ صحة الفرضية أعلاه والتي تشير الى تباين الطلب

$$
\text { السياحي في اقليم كوردستان العراق حسب أماكن الاقامة. }
$$

\section{6 تنوع مصادر العرض السياحي في اقليم كوردستان العراق.}

تبين من خلال الدراسة الى تنوع مقومات العرض السياحي في اقليم كوردستان العراق، اذ تعد بيئة الاقليم بيئة غنية بالمقومات السياحية، اذ يتمع الاقليم بالثراء الطبيعي والمناخ اللطيف والحياة البرية والموارد المائية والنبات الطبيعي، الى جانب تيك
كما أن القرارات الادارية التي تتخذ ستكون جاعية، لذا فهناك فرصة كيرة لنجاح تلك

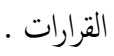

واشار (34.95\%) من المديرين الذين تم أستطلاع ارائهم بأنهم لا يؤيدون مبدأ الثراكة في الاستثمار ما بين القطاع العام والقطاع والخاص. ويعزو الباحث هذه النتيجة بأن الشراكة الاستثمرية في العمل قد يتولد عنه جملة من السلبيات كحصول حالة السخط المتراكم والناتج من العجز الملالي، والاختلاف الطبقي والسلوكي واختلاف الاهداف، وفقدان مبدأ المساواة نتيجة سيطرة أحد الشركاء، وصعوبة حل الخلافات بين الأطراف المختلفة، كلها أسباب منطقية قد تؤدي الى فشل المشروع الاستثمري.

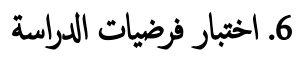

1.6 يزداد الطلب السياحي في اقليم كوردستان سنويا وبشكل منتظم اللترة من

(2013-2007)

تشير نتائج الحاسبة الكلكتونية بأن عدد السياح كن في تزايد مستمر سنويا خلال الفتزة ما بين (2007-2013)، اذ بلغ عدد السياح في اقليم وفي محافظات اربيل والسليمنية ودهوك (377,397) عام (2007)، وكان هذا العدد في تزايد مستمر خلال السنوات اللاحقة حتى وصل العدد الى (2,952,027) عام (2013)، وتؤكد النتأُ صحة الفرضية أعلاه والتي تشير الى تزايد الطلب السياحي سنويا في الاقليم. 2.6 يتيز الطلب السياحي في اقليم كوردستان بالموسمية. تشير نتاجُج الجدول ( 26) الى أن هناكُ تباين في عدد السياح في اقليم كوردستان العراق حسب فصول السنة خلال العام ( 2013)، اذ بلغ مجموع عدد السياح خلال فصل الشتاء (583876 ) سائُ، وأزداد هذا العدد خلال فصل الربيع ليصل الى (9117) ، ،ما أزاد هذا العدد خلال الصيف ليصل الى (978532) سائ، وأخخضض العدد ليصل الى (684211) خلال فصل الخريف، كما نجد بأن هناك تباين في اعداد السياح خلال فصول السنة من عام ( 2014)، اذ بلغ بموع عدد السياح خلال فصل الشتاء (575867) سائ، وأخخضض هذا العدد خلال فصل الربيع ليصل 
الفرضية أعلاه والتي تنص الى أن التسهيلات والحوافز التي تقدها حكومة الاقليم تشجع على الأستثمار في القطاع السياحي، الجدول (15). 8.6 ضعف المنافسة بين المنشات السياحية في اقليم كوردستان العراق. تشير ننائُ الدراسة الميدانية بأن المنافسة بين المنشات السياحية في الاقليم قوية، مما ها تها يؤكد عدم صحة الفرضية أعلاه والتي تنص الى ضعف المنافسة بين المنشات السياحية

\section{6 ضعف الأساليب التسويقية والتويية السياحية التي تقوم بها الحكومة} تشير نتائُ الدراسة الميدانية الى وجود ضعف في الأساليب التسويقية والترويجية، ويعود السبب في ذلك الى جملة من الأسباب منها وجود تقصير حكوي في هذا المجال وقلة الخبرة والكفاءة في مجال التسويق والترويج السياحي وغياب استراتيجية مشتركة بين القطاعين العام والخاص، فضلا عن ضعف دور الوزارة والهيئة العامة للسياحة في ذلك، مما يؤكد صحة الفرضية أعلاه والتي تنص الى ضعف الأساليب التسويقية والترويجية السياحية التي تقوم بها الحكومة. 10.6 ضعف دور الهيئة العامة للسياحة في تنشيط الطلب السياحي والاستثار

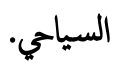
تشير نتائج الدراسة الميدانية الى ضعف دور الهيئة العامة للسياحة في تنشيط الطلب السياحي والاستثمر السياحي، ويعود السبب في ذلك الى جملة من الأسباب منها أن الأساليب التسويقية والتزويية التي تستخدما الهيئة العامة للسياحة ما زالت كلاسيكية وغير فعالة ضعف البنية التنظيمة للهيئة وضعف التنسيق مع الوزارات والجهات المعنية بالسياحة في الأقليم، فضلا عن فشل ادارات الهيئة العامة للسياحة في رسم أستراتيجية هادفة للقطاع السياحي الخاص في الاقليم، مما يؤكد صحة الفرضية أعلاه والتي تنص الى ضعف دور الهيئة العامة للسياحة في تنشيط الطلب السياحي والاستثمار السياحي.

\section{6 ضعف الدور الاقتصادي للقطاع السياحي في الاقليم.}

تشير نتائُ الدراسة الميدانية الى أن الدور الاقتصادي للقطاع السياحي كان متوسطا، ويكمن هذا الدور في عدد من الجوانب منها توفير فرص العمل ورفع معدلات التنمية والتخفيف من الفقر في الاقليم وزيادة الايرادات العامة للاقليم وغيرها من المجلات

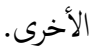

وقوع الاقليم في موقع حضاري كم مرت عليه الحضارات، وتزكت فيه اثارا خالدة الى الأبد. هذه المقومات تثير الأفراد وتدفعه الى السفر نحو مناطق تواجدها، ويؤكد العرض السابق الى صحة الفرضية أعلاه والتي تشير الى تنوع مصادر العرض السياحي

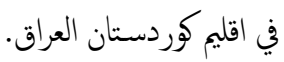

5.6 تنوع بجالات الأستثمارات السياحية في اقليم كوردستان العراق.

تشمل مجالات الأستثمر السياحي في الاقليم بمنشات الايواء (كالفنادق والموتيلات والقرى السياحية )، وتشير احصاءات الهيئة العامة للسياحة الى تزايد عدد هذه المنشات خلال الفنزة (2007-2014 )، كما تشمل مجالات الأستثمر المطاع أيضا، وتشير احصاءات الهيئة العامة للسياحة الى تزايد عدد المطاع خلال نفس الفترة، وتشمل مجالات الاستثمار مكاتب السفر والسياحة، اذ يبلغ عددها ( 156) شركة منها ( 83 ) شركة في محافظة أربيل وبنسبة( 53.2 ) ، تليها محافظة دهوك ( 42 ) شركة بنسبة\% (26.9 ) أما في محافظة السليانية فقد بلغ عددها ( 31 ) شركة وبنسبة (19,9\% ) من الجمموع الكلي، كما يكن الاستثمار في مجال النقل بانواعه المختلفة، والبحث العلمي والمقاهي السياحية ومدن الكلاب والملاعب الرياضية، وتؤكد النتائُ السابة الى صحة الفرضية أعلاه والتي تشير الى تنوع مجالات الاستثمارات السياحية في اقليم كوردستان العراق.

\section{6 ضعف الأستثمارات السياحية في اقليم كوردستان العراق.}

تشير نتأُ الدراسة الميدانية بأن هناك ضعف في الاستثمارات السياحية في الاقليم، ويعود السبب في ذلك الى بمحوعة من الأسباب نذكر منها الاتي: عدم ملائمة المنشات السياحية لحاجات ورغبات السياح، وعدم وجود تخطيط للاستثارات السياحية وعدم توزعها بما يتوافق مع العرض السياحي في جميع مناطق الاقليم وقلة عدد شركات الادارة الفندقية ذات الخبرة العالمية وقلة عدد المنشات السياحية التي تستقبل السياح، ويؤكد العرض السابق الى صحة الفرضية أعلاه والتي تشير الى ضعف الأستتمرات السياحية في اقليم كوردستان العراق.

7.6 تشجع التسهيلات والحوافز التي تقدما حكومة الوقليم للاستثار في القطاع

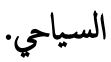
تشير نتأُج الدراسة الميدانية بأن التسهيلات والحوافز التي تقدما حكومة الاقليم متوسطة وغير مشجعة للاستثمار في مجال القطاع السياحي، مما يؤكد عدم صحة 
المختلفة ومجال البحث العلمي والمقاهي السياحية ومدن الألعاب والملاعب

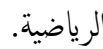

تبين من خلال نتائُ الدراسة الميدانية أن معظم مديري المنشات السياحية في الأقليم من الذور مقابل نسبة ضئيلة من الاناث.

تبين بأن معظم مديري المنشات السياحية في الأقليم تقع أعمارهم ما بين (2534) سنة، وهي فئات تقع في مستويات منخفة من النضج الفكري والعقلي. تبين بأن عدد المنشات السياحية ذات الحمس نجوم والأربع نجوم قليلة جدا، ولا يتناسب مع المستوى الثقافي والأجتاعي لبعض السياح وخاصة الأجانب منهم. تبين بأن معظم المستتمرين للمنشات السياحية من اقليم كوردستان، مقابل عدد قليل من المستتمرين الاخرين. أحتل واقع الأستثمار في الاقليم حسب وبحة نظر المديرين في المنشات

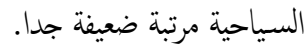

تبين بأن مستوى الخدمات السياحية المقدمة الى السياح متدنية، ويعود السبب في ذلك الى ضعف الرقابة من قبل الجهات المعنية. تبين بأن أغلب المستثمرين يفضلون الأستثمار في المدن السياحية بدلا من

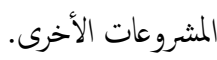

تبين بأن أغلب المستثمرين يفضلون الأستثمار في المنشات السياحية ذات

$$
\text { التصنيفات العالية كالمّس نجوم والأربع نجوم. }
$$

تبين بأن المنافسة قوية بين المنشات السياحية في الاقليم، وهذا شىء طبيعي لان الكل يرغب في الحصول على دخل المستهاك وكسبه لتحقيق المزيد من

تبين عدم وجود وحدة متخصصة للتسويق والترويج السياحي في أغلب المنشات

$$
\text { السياحية. }
$$

تبين ضعف دور الهيئة العامة للسياحة في تنشيط الطلب السياحي والأستثمر

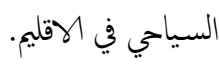

وفي السياق نفه تشير احصاءات وزارة التخطيط العراقية لعام 2013 بأن عدد العاملين في انشطة المطاعز وخدمات الطعام في محافظات اقليم كوردستان العراق يبلغ

(2609) في محافظة اربيل، كما تشير احصاءات وزارة التخطيط في اقليم كودستان

- لعام 2015 بأن عدد العاملين في مطاري اربيل الدولي والسليمنية الدولي قد بلغ (1,013) عامل عام 2013، فيا بلغ عدد العاملين في المطارين المذكورين عام 2014، (1,051) . وعليه تشير النتائج السابقة الى عدم صحة الفرضية أعلاه. 12.6 ضعف الدور الاجتاعي للقطاع السياحي في الاقليم. تشير نتأُج الدراسة الميدانية الى أن الدور الاجتماعي القطاع السياحي كان جيدا، ويكمن هذا الدور في عدد من الجوانب منها خلق روح المجبة والوحدة بين المجتمعات المتنوعة وتنمية المجتع واحياء الفنون التقليدية وتنمية الصناعات اليدوية وغيرها من الجوانب الاخرى، مما يؤكد عدم صحة الفرضية أعلاه والتي تنص الى ضعف الدور الاجتماعي للقطاع السياحي في الاقليم. 13.6 يؤيد المديرين مبدا الشراكة ما بين القطاع العام والقطاع الخاص. تشير نتاجُ الدراسة الميدانية المى ان نسبة كيرة من المديرين الذين استطلعت ارأهم يؤيدون مبدا الشراكة ما بين القطاع العام والقطاع الخاص لوجود جملة من الايمابيات في هذا الجانب، مما يؤكد صحة الفرضية اعلاه والتي تنص الى ان المديرين يؤيدون مبدا الشراكة ما بين القطاعين.

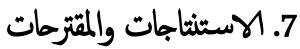

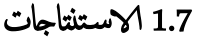

وفرت حكومة أقليم كوردتان العراق فرصة الأستثمار في مختلف قطاعات الأقتصاد الوطني، ومنها القطاع السياحي. وفرت حكومة أقليم كوردستان العراق فرصة أخرى تتمثل بالاعفاءات الضريبة والكمركية للمستثمرين في القطاعات الأقتصادية، ومنها القطاع السياحي.

قدمت حكومة اقليم كوردستان العراق ضانات ومحفزات للمستثمرين للأستثمار في القطاعات الأقتصادية، ومنها القطاع السياحي. تتميز محافظات اقليم كوردستان بتوفر مجالات عديدة للأستثمار السياحي كنشات الايواء والمطاع السياحية ومكاتب السفر والسياحة والنقل بأنواعه 
تشجيع المستثمرين العراقيين والأجانب، وتوفير مزيد من الفرص لمم للاستثمار في الاقليم لما للاستثمر الخارجي من دور همم في تحتيق التنمية الأقتصادية

والأجتاعية.

ضرورة رفع مستوى التسهيلات والتحفيزات للمستمرين للأستثمار في القطاع

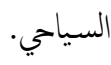
ضرورة متابعة المنشات السياحية والرقابة عليها ومحاسبتها لتقديم خدمات تتسم بالتميز، وبما يتناسب مع المستويات الثقافية والأجتاعية والأقتصادية العالية<smiles>[AlH][Te]</smiles>

ضرورة تشجيع المستثمرين للأستثمار في مختلف المشروعات السياحية بدلا من التزكيز على مشروعات معينة دون أخرى لما للتزكيز من تأثير سلبي على الوضع الأقتصادي، لذلك لا بد من تحقيق نوع من التوازن في المشاريع الأستثمرية. ضرورة تشجيع المستثمرين للأستثمار في متتلف تصنيفات المنشات السياحية ليتناسب ذلك مع دخل مختلف السياح، اذ أن السياح ليسوا متساوون في

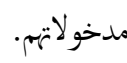

ضرورة تشجيع المنافسة العادلة وذات الأصول العلمية بين المنشات السياحية لما لذلك من تأثير ايجابي على تحسين جودة الخدمة السياحية التي تقدما المنشات

السياحية.

ضرورة تشكيل وحدات خاصة في المنشات السياحية تتولى تممة القيام بالأنشطة التسويقية والترويية للقطاع السياحي في الاقليم. ضرورة تفعيل دور الهيئة العامة للسياحة في تنشيط الطلب السياحي والأستثمار السياحي لكونها من الجهات المعنية بذلك. ضرورة تشجيع القطاع السياحي في الاقليم لمال لها من دور كير في تحقيق التنمية |لاقتصادية.

ضرورة تشجيع القطاع السياحي في الاقليم لمال لها من دور كبير في تحقيق التنمية الاجتاعية.

ضرورة أن تأخذ حكومة الاقليم آراء مديري المنشات السياحية فيا يتعلق بتحقيق مبدأ الشراكة بين القطاع العام والخاص.
• • بين بأن هناك دور كير القطاع السياحي في تحقيق التنمية الأقتصادية في الاقليم. تبين بأن هناك دور كير للقطاع السياحي في تحقيق التنمية الأجتاعية في الاقليم. تبين بأن غالبية المديرين في المنشات السياحية يفضلون مبدأ الشراكة بين القطاع العام والقطاع الخاص فيما يتعلق بالأستثمارات السياحية. تبين بأن عدد السياح في تزايد مستمر خلال الفترة الزمنية (2007-2013) في 1 الاقليم. - n تبين بأن الطلب السياحي في الاقليم بتميز بالموسمية. 2.7 ضرورة أستغلال الفرصة التي وفرتها حكومة أقليم كوردستان للمستمثرين من داخل الاقليم وخارجها للأستثمار في مختلف القطاعات الأقتصادية ومنها السياحة. ضرورة أستغلال الفرصة التي وفرتها حكومة الأقليم اللمستثمين، فيا يتعلق بالاعفاءات الضريبية والكمركة.

ضرورة قيام المستثمرين بالأستفادة من الضمانات التي وفرتها حكومة الاقليم لم بخصوص ضمان مشروعاتهم الأستثمرية. ضرورة أستغلال توفر مجالات الأسثمار السياحي المتنوعة في الاقليم من قبل المسثمرين، فتنوع المجالات فرصة كيرة قد لا يتوفر في دول أخرى. ضرورة توفير مزيد من الفرص للاناث لتسلم المهام الادارية في ختتلف المنشات السياحية لتحقيق العدالة الاجتماعية. ضرورة اختيار الفئات العمرية ما بين (35) فاكثر لكونه يمتلكون النضج الفكري ويتسمون باتخاذ القرارات المناسبة. ضرورة التركيز على اقامة منشات سياحية ذات الدرجات العالية لأن معظم السياح ذات ثقافة عالية ومركز أجتاعي عالي وقدرة أقتصادية عالية، وخاصة الأجانب منهم، لذلك يتطلب الأمر توفير منشات تناسب ومستوى هؤلاء 


$$
\begin{aligned}
& \text { ضرورة أستغلال فرصة تزايد عدد السياح في الاقليم والأستفادة نهم }
\end{aligned}
$$

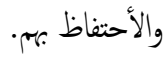

$$
\begin{aligned}
& \text { ضرورة القضاء على موسمية السياحة من خلال اقامة المؤتمرات والمعارض في } \\
& \text { فصول الكساد السياحي. }
\end{aligned}
$$

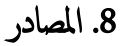

$$
\begin{aligned}
& \text { 1. أبو نعمة، عبد العزيز ، تسويق الخدمات المتخصصة، ط1، الوراق، عمان، الأردن، 2005م. } \\
& \text { 2. البطاط، كاظم احمد ومحد الزويني، تحليل دالة الاستثمار السياحي في محافظة، المؤمتر العلمَي } \\
& \text { الثالث، جامعة اهل البيتيت، المجلد 1، العدد } 4 \text { ،2006. } \\
& \text { 3. بوعموشة، حميدة، دور القطاع السياحي في تمويل الأقتصاد الوطني لتحقيق التنمية المستدامة- } \\
& \text { دراسة حالة الجزائر رسالة ماجستير، كلية العلوم الأقتصادية والتجارية وعلوم التسيير، جامعة } \\
& \text { فرحات عباس (سطيف) 2011-2012م. } \\
& \text { 4. بظاظو، ابراهيم، واخرون، السياحة البيئية بين النظرية والتطبيق، ط1، مؤسسة الوراق } \\
& \text { اللنشر والتوزيع، عمان، } \\
& \text { 5. مد، سعد ابراهيم، تخطيط وتنمية خدمات السياحة الدينية وأثرها في نمو الطلب السياحي } \\
& \text { في محافظة بنيوى، أطروحة دكتوراه، جامعة سانت كلمنتس العالمية، 2008م. } \\
& \text { 6. عبد العزيز، ماهر توفيق، مبادئ ادارة الفنادق، المكتبة الوطنية للنشر، عان، الأردن، } \\
& \text { 1996 } \\
& \text { 7. رزيق، عبد الوهاب، منتدى الاستثمار في شمال افريقيا، المركز الإنمائي لشمال افريقيا، نشرة }
\end{aligned}
$$

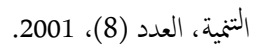

$$
\begin{aligned}
& \text { 8. محمد، حكأم مسن، دور الاستثمار السياحي العربي والاجنبي في دع الاقتصاد العراقي، } \\
& \text { المؤتمر العلمي الثالث لجامعة اهل البيت، العدد (4)، كربلاء، 2006، }
\end{aligned}
$$

9. Bahram Meihami, Jasim Karami, Review Some Effects of the Investment in the Tourism Sector (Evidence of the Qhorveh City), International Letters of Natural Sciences Online, Vol. 25, 2014.

10. Endo, Kumi, Foreign Direct Investment in Tourism-Flows and Volumes, Tourism Management 27(4), 2006.

11. http://www.alukah.net/culture/0/53460

12. UNWTO, 2007. 